\title{
An indicator-based sustainability assessment method for indigenous communities: a case study from Mexico
}

\author{
Jessica Molina Maturano ${ }^{1}$ (D) - Luz A. García Serrano ${ }^{1}$ (D) - Juan A. Carmona García ${ }^{2}$ (D) . \\ Mayela A. García de Alva Magos ${ }^{3}$ (D) Anna M. Hersperger ${ }^{4}(\mathbb{D}$
}

Received: 14 April 2020 / Accepted: 2 June 2021 / Published online: 4 July 2021

(c) The Author(s) 2021

\begin{abstract}
Indigenous and Western communities are faced with increasing issues of sustainability compromising their natural resources and cultural heritage, for example, a cross-pollination/complementary approach in relation to their current knowledge systems and discourses on sustainability. There is a need for methods that integrate different discourses relating to sustainability to identify the most pressing needs in terms of sustainability. Sustainability assessments are a type of impact assessment that focus on enhanced sustainability both now and in the future; however, the literature on indigenous sustainability assessment methods, is scarce. To address this gap, we have developed a novel Sustainability Assessment method for Indigenous Communities (SAIC). The SAIC method combines Western and indigenous sustainability objectives and principles, in order to extend the range of options for action to address sustainability. The SAIC method consists of two sections (i) values and considerations and (ii) procedure. The "values and considerations" section establishes the fundamental participatory and ethical considerations for conducting sustainability assessments in indigenous communities, and the "procedure" section establishes a set of 55 indicators in eight categories. The method was tested in a Zapotec, indigenous community in México. Results show that this community was rated highly in all eight categories. However, indicators for family planning and access to health services were rated poorly. The identified issues can be used as guidelines for decision making in future regional projects and development plans. The results reveal further areas for improvement, such as strengthening the links to national or international networks and increasing the use of renewable energies. The method presented in this paper provides an assessment approach based on Western and indigenous sustainability discourses, which is suitable for assessing indigenous communities.
\end{abstract}

Keywords Indigenous sustainability · Sustainability indicators · Sustainable development · Indigenous people

Jessica Molina Maturano

jmolinam1600@alumno.ipn.mx

Extended author information available on the last page of the article 


\section{Introduction}

Sustainability assessments are a type of impact assessment that focus on enhanced sustainability both now and in the future. A sustainability assessment is thus an especially promising approach for local-level assessments of sustainability (Sala et al., 2015). Indeed sustainability assessments are useful in obtaining information relating to the major sustainability issues in terms of their context and complexity (Bond \& Morrison-Saunders, 2011). Sustainability assessments have been carried out in local studies, focusing on specific topics such as tourism (Choi \& Sirakaya, 2006), ecotourism (Ocampo et al., 2018) and forest management (de Oliveira et al., 2018; Duffield et al., 1998).

Sustainability assessments have also been applied to assess the level of achievement of sustainable development in Latin American countries (Toumi et al., 2017). However, this method has rarely been adapted to the characteristics and contexts of indigenous communities. Efforts to develop an integral model have previously been proposed and are expected to provide information on sustainability in indigenous communities (Galván-Martínez et al., 2016, 2020). However, to date these studies do not integrate sustainable Western and indigenous discourses, neither do they establish guidelines for interactions in sustainability studies within indigenous communities.

Indigenous and Western communities have recognized the great importance of measuring sustainability at local level. Both communities are constantly seeking new methods and solutions and have expressed their willingness to learn and to feedback into their knowledge systems. Indigenous and Western sustainability knowledge are in close interaction (Agrawal, 1995; Quarrie, 1992; Richardson, 2011), and their discourses on sustainability can complement one other in an indicator-based approach.

The combination of indigenous and Western discourses on sustainability in a single study, is expected to have several benefits: it promotes an equitable valuation of knowledge without hierarchy and allows for a more multifaceted approach and the creation of new inferences. Using indigenous elements to develop indicators can lead to effective local action, as well as communication relating to local needs (Sterling et al., 2017). Indeed, incorporating different elements from Western sustainability discourses into indigenous sustainability discourses and vice versa has been shown to improve discourse outcomes (Quarrie, 1992; Richardson, 2011). Studies have incorporated indicators referring to the other sustainability discourse to achieve a better evaluation of sustainability at local level. For example, indigenous sustainability evaluation studies have used Western sustainability indicators (Da Silveira, 2005). In parallel, the importance of social and qualitative indicators, and knowledge of the local environment, has been tested by Western expertise (Duffield et al., 1998; Fagerholm et al., 2012). Some Western studies have explicitly recognized the importance of including cultural and historical indicators in sustainability discourses (Duffield et al., 1998).

A method to evaluate the sustainability of indigenous communities at local level should integrate both indigenous and Western sustainability discourses, to expand the range of options available to address sustainability issues (Mistry \& Berardi, 2016). However, a tested method, integrating Western and indigenous sustainability assessment is lacking. Accordingly, this study proposes the SAIC method, which integrates both Western and indigenous sustainability discourses. This method is based on a framework that determines certain values, i.e., moral standards and considerations (referred to as "values and considerations" in this paper) and guidelines (referred to as "procedure" in this paper) aimed at conducting an intercultural sustainability study. The SAIC method has been designed to 
identify the main sustainability issues. This method was tested during an assessment of an indigenous Zapotec community in Mexico.

This study is composed of theoretical background (Sect. 2) and its application in the study area of the community of Teotitlán del Valle. The "methods" are presented in Sect. 3; "Methods" and the "results" in Sect. 4. Finally, the results and limitations are discussed and conclusions are drawn.

\section{Theoretical background}

Frameworks are useful for assessments as they frame, research principles, values and context (Bond \& Morrison-Saunders, 2011; Sala et al., 2015) and facilitate the description of ethics and scalability (Sala et al., 2015). Such a theoretical structure is particularly useful in adequately addressing the characteristics of indigenous communities, as well as their definitions of sustainability. The conceptual framework for this research is based on an adaptation of the systematic guidelines for sustainability assessment by Sala et al. (2015) and has been specifically adapted for the indigenous communities. In the following section, we describe how the proposed SAIC method addresses "values and considerations" and "procedure" (see Fig. 1).

\begin{tabular}{|c|c|}
\hline \multicolumn{2}{|c|}{$\begin{array}{c}\text { SAIC } \\
\text { VALUES AND CONSIDERATIONS }\end{array}$} \\
\hline $\begin{array}{l}\text { SUSTAINABILITY } \\
\text { CONTEXT }\end{array}$ & $\begin{array}{l}\text { - Main economic activity } \\
\text { - Sustainability }\end{array}$ \\
\hline GUIDING VISION & $\begin{array}{l}\text { - Western sustainability } \\
\text { - Indigenous sustainability }\end{array}$ \\
\hline $\begin{array}{l}\text { ESSENTIAL } \\
\text { CONSIDERATIONS }\end{array}$ & $\begin{array}{l}\text { - Indigenous otherness } \\
\text { - Research ethics } \\
\text { - Sustainability science } \\
\text { - Research paradigm }\end{array}$ \\
\hline $\begin{array}{l}\text { ADEQUATE } \\
\text { SCOPE }\end{array}$ & $\begin{array}{l}\text { - Indigenous communities } \\
\text { - Current situation } \\
\text { - Local level }\end{array}$ \\
\hline TRANSPARENCY & $\begin{array}{l}\text { - Comunication of results } \\
\text { - Clear and plain language }\end{array}$ \\
\hline $\begin{array}{l}\text { BROAD } \\
\text { PARTICIPATION } \\
\text { OF } \\
\text { SKATEHOLDERS }\end{array}$ & $\begin{array}{l}\text { - Identification of } \\
\text { sustainability issues } \\
\text { - Participatory } \\
\text { development and } \\
\text { proposition of solutions }\end{array}$ \\
\hline
\end{tabular}

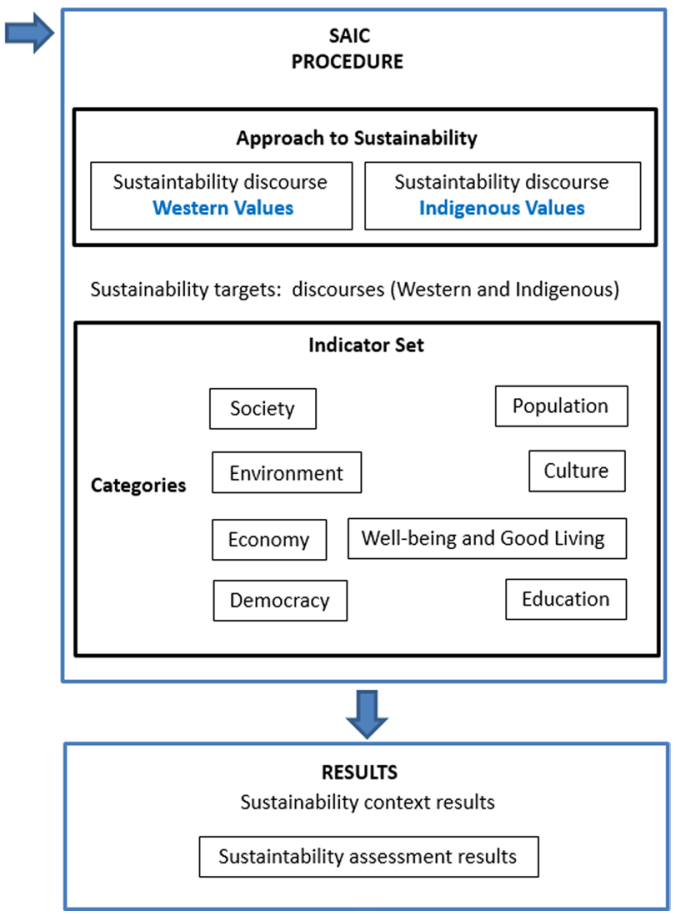

Fig. 1 Schematic representation of the SAIC method with "SAIC values and considerations" and the " SAIC procedure." Indigenous and Western sustainability discourses are highlighted in blue. Adapted from Sala et al. (2015) 


\subsection{SAIC basis: values and considerations}

The section relating to "values and considerations" is based on theories and perspectives to establish a basis for interaction among community participants and researchers. Key elements are therefore: the sustainability context, guiding vision, essential considerations, appropriate scope, transparency and board engagement with stakeholders (Fig. 1, left side). These values and considerations aim at promoting equal and transparent connections between participants and their knowledge systems and include elements focused on facilitating interaction and knowledge synergies between participants.

The "sustainability context" is based on different knowledge interaction recommendations (Calleros-Islas, 2019; Raymond et al., 2010; Santana-Medina et al., 2013). This first step should enable the researcher to understand the main economic activities of the community, identify the stakeholders and obtain a general context overview of the community. This step involves surveys and focus groups, and the information obtained from it is mainly used to interpret the results of the SAIC.

The formulation of a "guiding vision" should consider aspects of Western and indigenous sustainability, relating to the definition of Western sustainability (Brundtland 1987) and the definition of indigenous sustainability (Galván-Martínez et al., 2016), to integrate both approaches to sustainability.

The "essential considerations" element stresses the inclusion of a community's social, economic and environmental aspects, in addition to their cultural and indigenous characteristics. Indigenous "otherness," research ethics, sustainability science and the research paradigm, lay the foundations for an inclusive and enriching intercultural dialog. Indigenous "otherness" (Leff, E., 2012) supports the recognition of indigenous knowledge about sustainability and formulates research ethics aimed at establishing the ethical guidelines for research into indigenous people (AIATSIS 2019; Wilson, 2003).

The sustainability science principles (Clark \& Dickson, 2003; Sala et al., 2013) enable the exchange of information between discourses within environmental studies and the research paradigm (Hart, 2010), as a theoretical guide to archive knowledge by means of collaboration between scientists and indigenous people, in accordance with participatory guidelines (Ander-Egg, 2003; Mistry \& Berardi, 2016) to establish an inclusive study.

The element "adequate scope" refers to the current sustainability status of an indigenous community adapted to a community geographical scope. Here both Western and indigenous sustainability indicators should be considered within a comprehensive set of indicators. Actions to ensure "transparency" should follow the recommendations of participatory research (Ander-Egg, 2003; Mistry \& Berardi, 2016), and ethical research elements should be used to empower communities, for example by communicating assessment results using clear and comprehensible language.

"The broad participation of stakeholders" should be ensured during the entire assessment process, specifically during feedback sessions to select indicators and during the discussion to identify solutions.

\subsection{SAIC Procedure: how sustainability is measured}

Once the values and considerations are established, the procedure (Fig. 1, right-hand side) can be conducted. The steps of the procedure consist of (a) assessing the approach to sustainability, (b) assessing sustainability targets, (c) applying the indicator set which 
combines Western and indigenous sustainability indicators and (d) interpreting the results (Fig. 1).

The "approach to sustainability" step is based on sustainability science. This holistic approach includes both Western and indigenous definitions and understanding of sustainability; thus, it is possible to link the values of the indigenous and Western sustainability discourses.

"Sustainability targets" are comprised of objectives, characteristics and principles of Western and indigenous sustainability. The main characteristics of both sustainability definitions should inform the procedure and be incorporated into the sustainability targets. Western characteristics include Sustainable Development Goals (SDGs), the characteristics of sustainable communities (Lu et al., 2017) and Agenda 21 objectives (Quarrie, 1992). Indigenous characteristics include the "good living objectives" derived from the recognition of the conceptions of sustainability and respect for nature, promoted by indigenous societies (Vivir.B. Ecuador-Quito, 2013) and characteristics related to the definition of indigenous sustainability (Galván-Martínez et al., 2016).

\subsection{Developing Western and indigenous criteria as indicators}

In the following paragraphs, we discuss the current state of Western and indigenous sustainability indicators and assessment methods. Sustainability studies acknowledge that indicators are a useful tool in the evaluation of sustainability. The indicators of each discourse are based on the respective definitions of sustainability and sustainability goals, plans, terms, theories and outcomes.

Western sustainability indicators are generally related to the definition of sustainability as a "development that meets the needs of the present without compromising the ability of future generations to meet their own needs" (Brundtland 1987). For example, local studies using this approach generally use "sustainable community" indicators (Lu et al., 2017), "Sustainable Development Goals" (SDGs) (Desa, 2016; Dizdaroglu, 2015) and "Agenda 21" plan indicators (Eckerberg \& Mineur, 2003; Lu et al., 2017; Mascarenhas et al., 2010). Indicators referring to a "sustainable livelihood" (Bozigar et al., 2016) have also been used to recognize the importance of poverty. Indicators related to "well-being" (Duffield et al., 1998; Fagerholm et al., 2012) have been employed in order to reaffirm the importance of satisfactory environment conditions, and social indicators (Duffield et al., 1998) have been used to investigate social sustainability issues.

Indigenous sustainability indicators are generally related to the definition of indigenous sustainability, defined by Galván-Martínez et al. (2016) as: "a process based on the valuation, preservation and transmission of indigenous cultures, which promotes the management of natural resources and their conservation for the following generations, starting with the recognition of indigenous territories, their limited socio-environmental conflicts, selfsufficiency in terms of food, their diverse productive activities and a regional economic exchange balance-from the community." The aforementioned definition was considered since it includes the identification of the community worldviews (Galván-Martínez et al., 2016) and takes into account "Buen Vivir" principles. Local studies generally use indicators based on different theories regarding the conservation of the natural, social, cultural and economic elements from the community's ontology and reality.

Indigenous sustainability indicators commonly consider elements such as autonomy, participation and self-determination. Such indicators have, for example, been used in studies on tourism (Sancho et al., 2007; Velázquez-Sánchez et al., 2014) and forest use 
(Luján-Álvarez et al. 2004). New indicators assessing the rurality of communities (AriasGutiérrez et al. 2015; Yissi and Cartes 2011) have highlighted the importance of social dynamics in local studies. Arias-Gutiérrez et al. (2015) aimed to understand the sustainable development of communities using social and economic indicators, such as the Sociodemographic Indicators System for Indigenous Populations and Peoples of Latin America (CELADE, 2012). The indigenous sustainability approach generally uses indicators based on "good living," a Latin American concept that includes education, environmental development, autonomy, participation, self-determination and principles and objectives that match the realities of indigenous communities (Vanhulst \& Beling, 2014). Similarly, "Buen Vivir" is a broad concept that includes aspects of life quality. "Buen Vivir" embraces the broad notion of well-being (Gudynas, 2011); it focuses on the idea that well-being is only possible when cohabitating with nature.

\section{Methods}

\subsection{Study area}

The indigenous Zapotec community of Teotitlán del Valle is located within the central valleys of Oaxaca, Mexico, at an altitude of 1600 m.a.s.l. The municipality belongs to the district of Tlacolula, in the State of Oaxaca in southern Mexico (see Fig. 2). It is located $30 \mathrm{~km}$ from Oaxaca City with easy access for tourists and is a prestigious tourist destination for handmade textiles. The community has approximately 10,000 inhabitants of which around $80 \%$ are dedicated to the production or marketing of textile crafts.

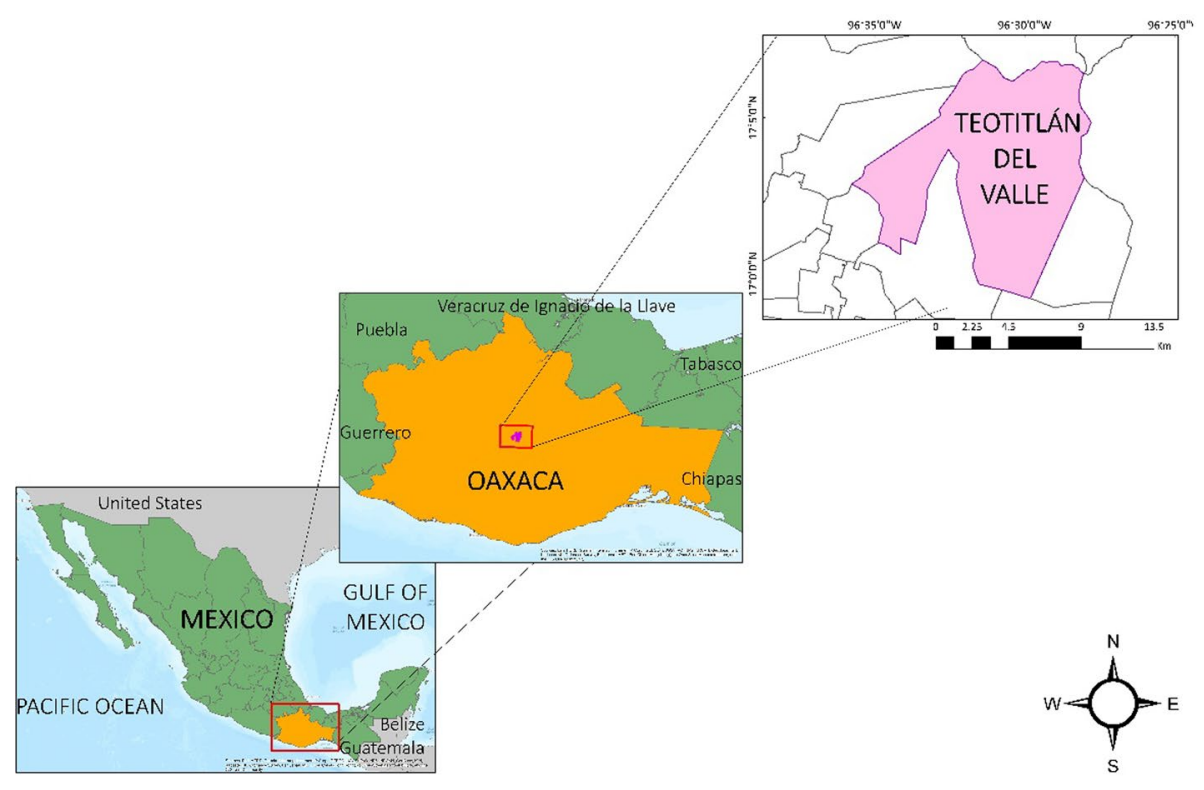

Fig. 2 Location of the study area. Teotitlán del Valle highlighted in purple, Oaxaca state in yellow and Mexico in green 
The community territory covers $81.65 \mathrm{~km}^{2}$, of which approximately $65 \%$ is forested, $27 \%$ is used for agriculture, $5 \%$ is covered by grassland, and $3 \%$ constitutes urban areas. The entire territory of Teotitlán del Valle is communal, i.e., the community as a whole is in charge of the management of their territory. The community of Teotitlán del Valle is governed by a communitarian alternative system known as "usos y costumbres" (habits and customs). The structure of this system is characterized by the community assembly, traditional authority, sectorial committees, the council of elders and the participation of the population in the form of benefits granted to the community (Mendoza 2011).

In the community of Teotitlán, there are archaeological remains of pyramids that were once built for the god Quetzalcóatl and other pre-Hispanic Zapotec deities. Although Christianity has been practiced since colonization, pre-Hispanic rites, religious beliefs and customs such as the Sacred Duality of the World (Hernández-Díaz, 2012), and the cult of Quetzalcoatl are still practiced.

Tourists also visit the community to admire the handmade candles and observe the main celebration of the town called "The Precious Blood of Our Lord Jesus Christ" in which parades and dances are performed once a year. The most representative dance is the "Danza de la Pluma," which tells the story of the struggle between Spanish soldiers and warriors under the command of Moctezuma, as a theatrical performance. Dance is a collective-individual commitment, which not only has religious and cultural importance, but also political importance within the government system (Hernández-Díaz, 2012).

The community interacts constantly with the city and the Western world, defined by tourist activity. Due to this interaction and its internal dynamics, it is constantly changing and is challenged with economic, social and environmental issues.

\subsection{Data collection}

\subsubsection{Agreement between the participants and research team}

The research team and the participants have a longstanding relationship on account of previous projects, related to the exchange of Western and traditional knowledge in the improvement of the textile process. This study assessed the sustainability status for the year 2018. During several visits to handcraft workers' groups, the population was invited to participate in the sustainability assessment. They expressed their interest as well as their concern in relation to sustainability issues and gladly agreed to participate in the process and the interviews. A study proposal was presented to the participants and discussed in a participatory meeting in which the purposes of the study and the intended results were explained. Participants were asked about their opinions, worldviews and experiences of sustainability in the community.

The meeting was organized by the first author and the participants in the community, who were guided by a cross-cultural dialog, based on indigenous otherness, sustainability science and the research paradigm. Indigenous sustainability was recognized as being equal in value, and ideas based on practices of respect ensured that a constructive dialog was exchanged. Participants were largely community artisans and ranged in age from 30 to 70 . All the participants were familiar with the concept of sustainability and showed an interest in participating as well as in learning about the key problems within the community. 


\subsubsection{Theory-based indicator selection}

The primary indicator set was compiled by analyzing 14 studies and documents based on indicators to measure sustainability at a local level. Furthermore, they were selected in such a way that they could demonstrate the general conditions of sustainability (MorenoPires et al., 2014) and local community contexts (Lu et al., 2017).

To address Western sustainability discourse, the following studies were taken into consideration: Western studies of sustainability assessment at local level including (Best et al., 2003; Dizdaroglu, 2015; Duffield et al., 1998; Eckerberg \& Mineur, 2003; Lu et al., 2017; Mascarenhas et al., 2010) networks of sustainable villages (Red de Ciudades y Pueblos Sostenibles de Castilla-La Mancha, 2009). Furthermore, documents referring to the theoretical Western sustainability discourse, i.e., The United Nations Conference on Environment and Development, the World Summit on Sustainable Development, Agenda 21 and SDGs (Desa, 2016; Quarrie, 1992) were integrated into the indicator set. Western sustainability assessment studies which focused on participatory approaches concerning local knowledge on sustainability (Da Silveira, 2005; Fagerholm et al., 2012), were also used to establish guidelines for the proposal of indicators.

From an indigenous perspective, the following studies were considered: (Arias-Gutiérrez et al. 2015; Del Popolo \& Schkolnik, 2005; Del Val et al., 2008; Yissi and Cartes 2011; Galván-Martínez et al., 2016; Sancho et al., 2007; Velázquez-Sánchez et al., 2014). Furthermore, indigenous indicators relating to "good living" (Buen Vivir) objectives and sociodemographic indicators for the indigenous population (CELADE, 2012; Vivir.B. Ecuador-Quito 2013) were also used, alongside studies related to indigenous participation in sustainability, such as those of Luján-Álvarez et al. (2004).

Each indicator was related to one or more aspects as follows: 25 indicators were directly linked to the SDGs, 27 indicators were linked to elements relating to sustainable communities', 26 indicators were linked to Agenda 21 goals, 25 indicators were linked to indigenous communities' characteristics, 17 indicators were related to well-being, and 50 indicators were linked to some of the "Buen Vivir" aspects, and the above is shown in Fig. 3.

"Buen Vivir" is a complete concept that includes political, social, economic and environmental aspects, emphasizing the quality of life of people in close contact with nature, such as many indigenous communities. This concept relates broadly to the characteristics

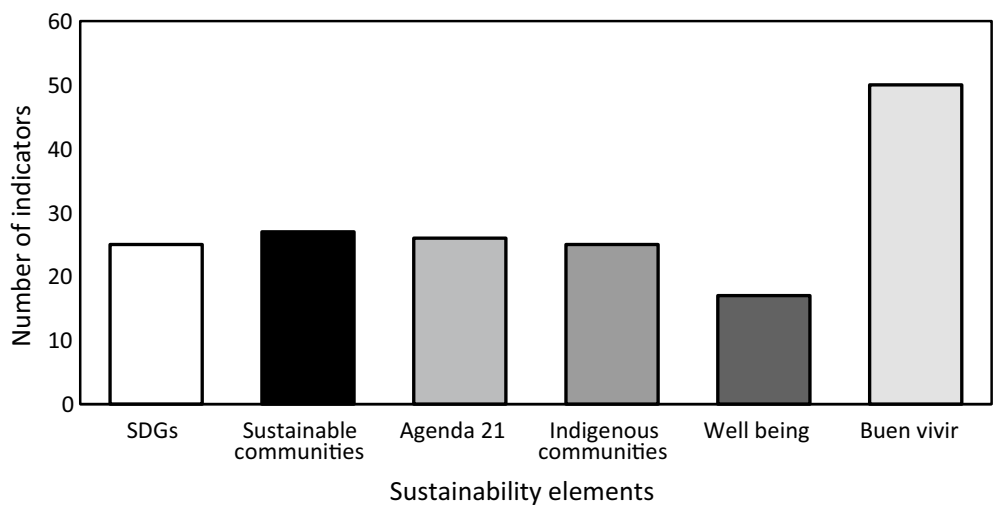

Fig. 3 Number of indicators related to the different sustainability elements 
of indigenous communities; therefore, it has been suggested that indicators related to "Buen Vivir" should be included in any indigenous sustainability assessment study. For this primary list of indicators, a preliminary scale for measuring was developed as well as a specification of the required data.

For the aggregated indicator values shown in Fig. 4, values were aggregated by category. First the ideal, i.e., theoretical maximum value per category was calculated by multiplying the number of indicators with the maximum value per indicator (5). Second, the case study results of all indicators in a category were added. Finally, the added case study results were expressed as percentage of the theoretical maximum values. This simple aggregation presents the information clearly, allowing participants and decision-makers an easy understanding.

\subsubsection{Participatory dynamics in indicator selection: integrating community members' feedback}

This primary list of indicators and rating scale was proposed to community members. The indicator set was developed within a participatory dynamic in Teotitlán del Valle. Feedback sessions with the participants were carried out in order to address local issues and engage local stakeholders in the monitoring, reporting and development of the results. Participants were closely involved in the co-creation of the indicator process. Indicators were discussed in feedback sessions (Preuss \& Dixon, 2012) and subsequently verified by the community, taking into account their social, cultural and environmental context.

Once the indicator set was selected, it was presented to the participants for its validation.

In the second feedback session, the indicators were verified by the participants. The validation was carried out based on the contexts, traditional practices and characteristics as an indigenous community.

It was discussed whether the scale for assessing literature was appropriate for the area of study. In order to evaluate the indicators, it was necessary to develop a value system, a scale based on four sustainability-ranking categories: "very good," "good," "moderate" and "poor" with respect to the concept of sustainability. Indicators were defined according

Fig. 4 Aggregated indicator values per category are shown in red, while the theoretical maximum values are shown in blue. Aggregated indicator values per category are given in present of the theoretical maximum values

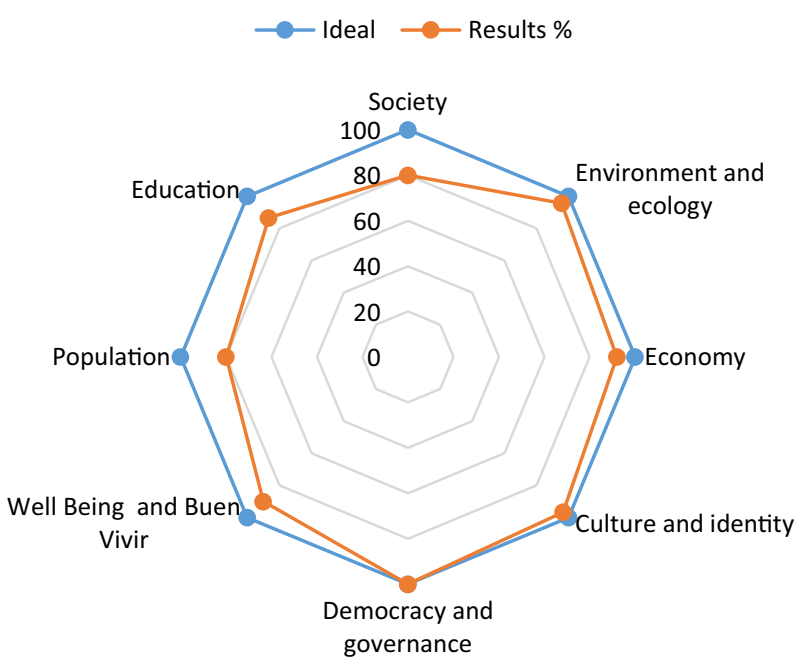


to the reference document or study (Appendix 1); the rating scale was established across four rating levels (values from 2 to 5) and the existence or non-existence was determined according to the same studies or through standards agreed during feedback meetings.

The standardization of the set of indicators might be applicable to other indigenous communities; possible changes in context should be addressed through feedback sessions. In these sessions, members of the community should verify whether the indicators and scales are appropriate to their community. The set of indicators was applied in the Zapotec indigenous community of Teotitlán del Valle, Mexico (see 3.3 Data collection). Finally, the results were shared with the participants to gain final insights and feedback. The evaluation range and units were specific for each indicator (for further information see Table 1 in Appendix 1).

\subsubsection{Primary and secondary data collection}

The importance of specifying the source of the data was highlighted during the previous feedback session. It was agreed that the source of the results is established, since this and other indigenous communities have a lack of government information. The options of obtaining results through primary and secondary data were agreed. Primary data were established in this study as the information obtained from interviews and observation. The secondary data refer to data obtained from governmental sources, i.e., INEGI.

Primary data were collected within one week in November 2018. Subsequently, 50 semi-structured interviews were conducted to collect information relating to the indicators. The interviews lasted approximately one hour and were conducted in Spanish. Two semistructured interviews required the assistance of a local translator in Zapotec. The interviews were recorded with prior permission from the participants. During the meetings, field notes were taken using a narrative context (Holzer et al., 2018) and the recordings were transcribed. The interviews followed the established methods of Mistry and Berardi (2016). Additionally, two researchers conducted focus-group meetings according to Bohnet (2010).

Secondary data (data concerning population demographics, and physical geography) were obtained from government institutions, such as the National Institute of Statistics and Geography, INEGI. Measurements were used to assess forest loss and count the number of natural sacred sites. Appendix 1 sets out the possible sources of data used for this study.

\subsubsection{Sharing the information}

After the application of the SAIC method, the results were provided to the participants for their use during a participatory meeting, in which the high and low aspects of sustainability were discussed. This meeting was useful in confirming the results alongside their perceptions, as well as establishing guidelines identifying which efforts should be focused on greater sustainability. During this meeting, actions were expressed in this regard, which are described in Sect. 5. 


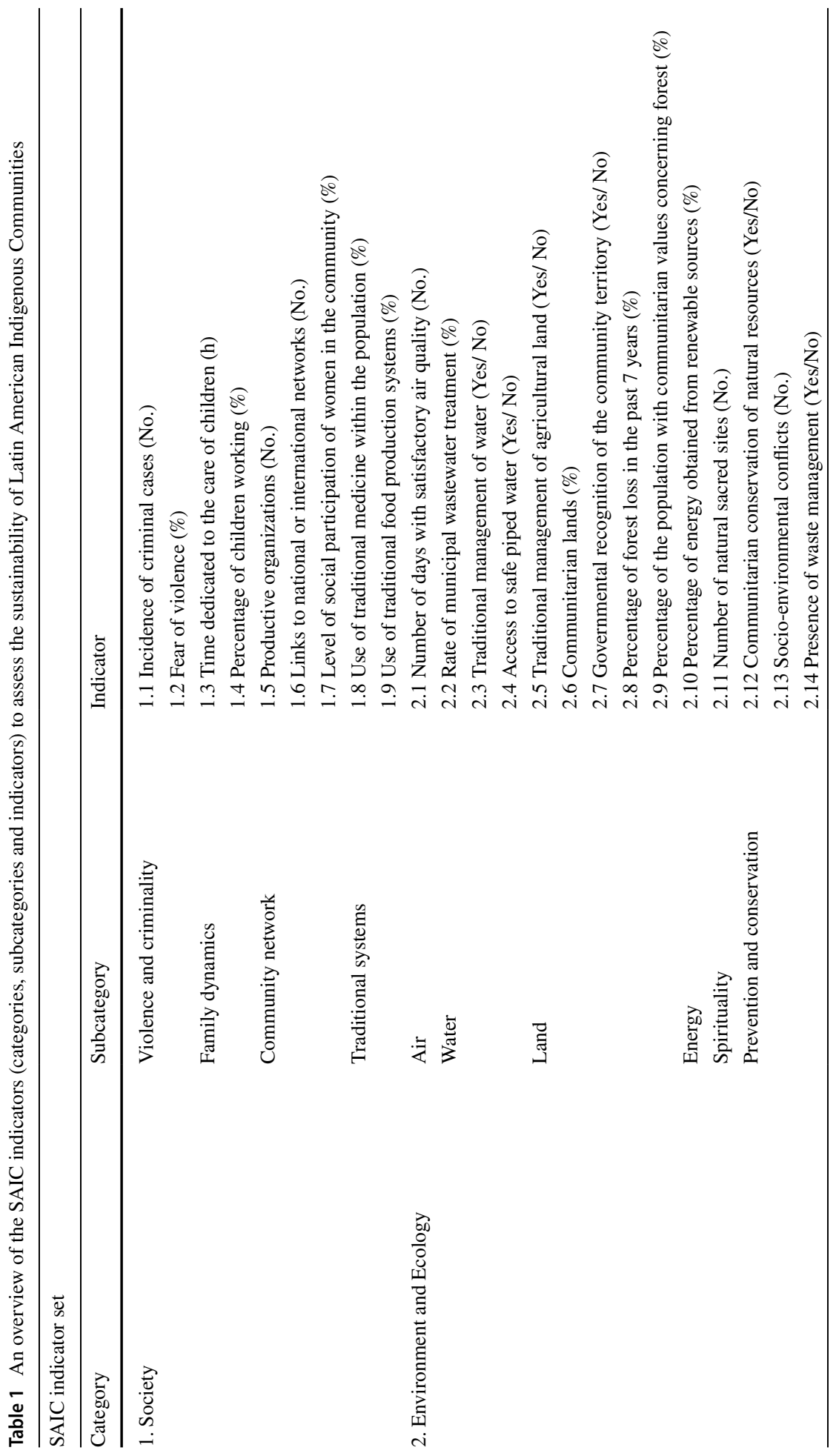




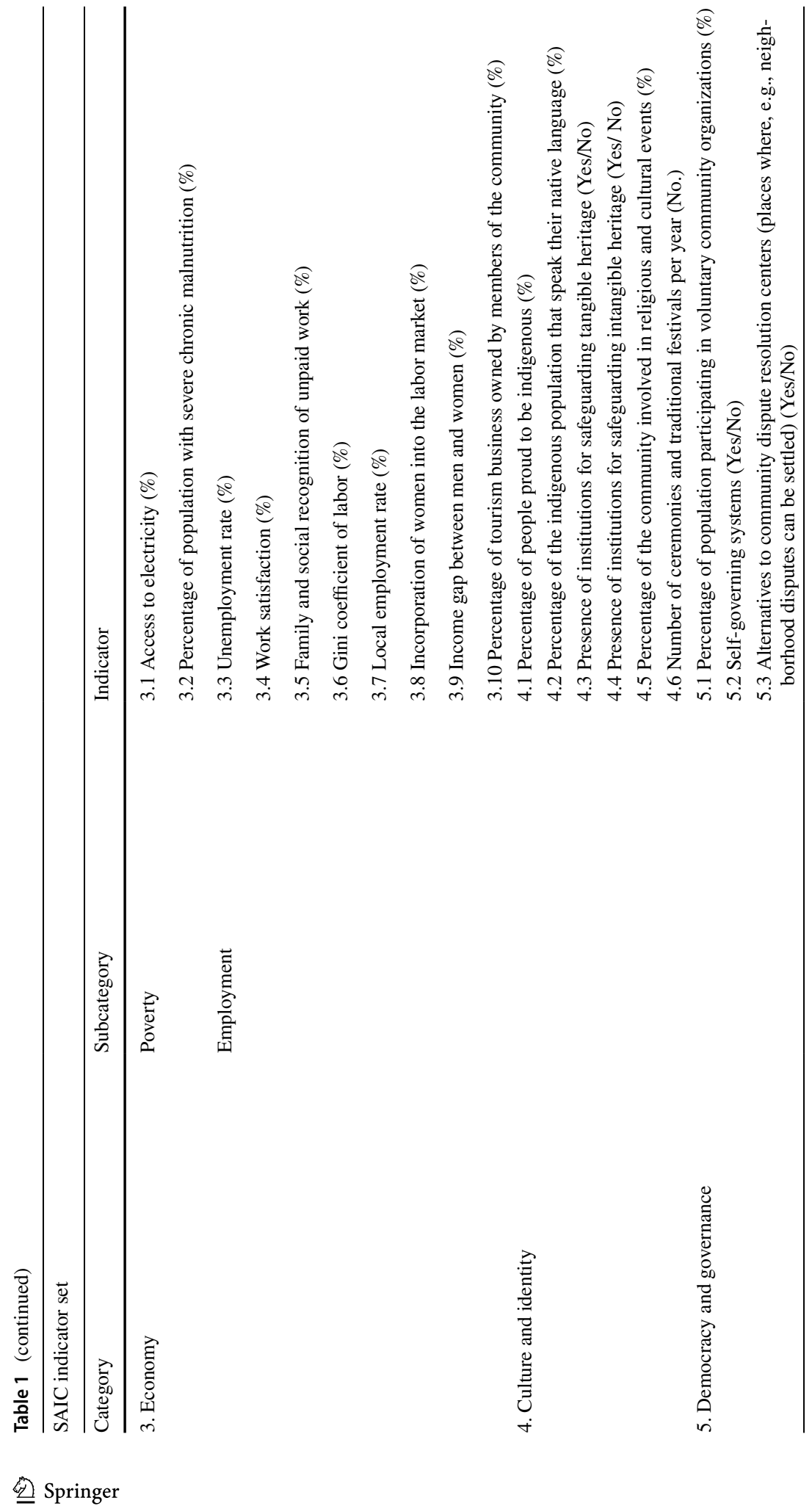




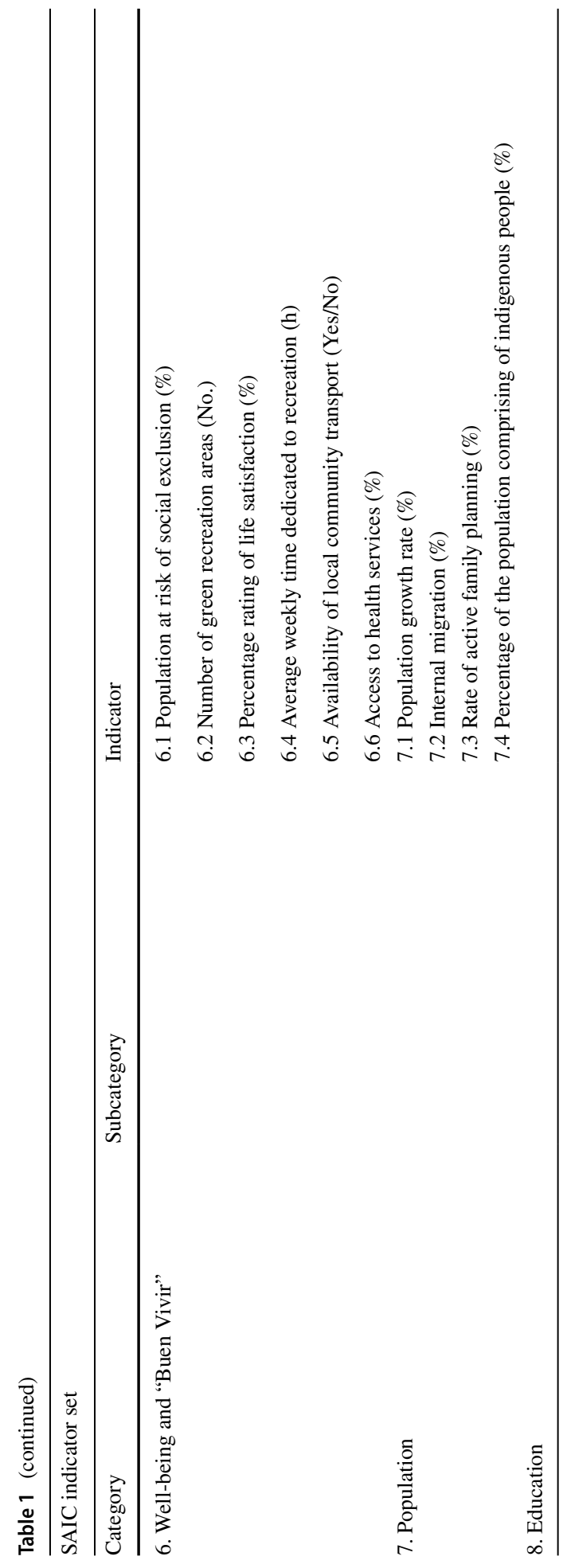




\section{Results}

\subsection{SAIC indicator set}

The indicator set was structured into eight categories, 12 subcategories and 55 indicators (Table 1).

A definition of each indicator, the study or document from which it was taken, the scale, the specification of adjustment of the scale to the size of the population, the source of the information and the final results of the community assessment are shown in Appendix 1.

\subsection{Sustainability assessment results}

The following sections explain the results for each category and highlight some of the highest and lowest indicator values (see data collection). All categories were rated as having sustainability levels of $80 \%$ and above. Nevertheless, it is important to analyze all indicator scores in detail to identify the main sustainability issues in the community, so as to address them and develop solutions.

"Democracy and governance" received the highest rating for sustainability as shown in Fig. 4. Most of the population of Teotitlán del Valle (80\%) are involved in voluntary community organizations. Voluntary organizations demonstrate indigenous community values, namely a sense of collective identity and commitment to other community members. Community values are also reflected in the self-governing systems (habits and customs) and alternatives to dispute resolution centers (meetings for community issues). These practices encourage the participation of local inhabitants and contribute to their democratic governance systems.

"Culture and identity" indicators were rated as having a sustainability level of $96 \%$. In total $97 \%$ of the interviewees were proud of being indigenous and $90 \%$ regularly attended traditional festivals. The high levels of indigenous pride may be related to the fact that heritage is considered something that is protected. Although sustainability levels for "culture and identity" were high, there was concern about the gradual loss of language. The results show that $70 \%$ of the population of Teotitlán del Valle speak Zapotec. However, during interviews, the adult population expressed concern about the loss of the native language among younger generations.

The Zapotec indigenous language is an important element of Zapotec identity and culture; the protection and promotion of this language is, therefore, vital.

The "environment and ecology" category was rated highly in terms of sustainability (95.7\%) denoting an almost spiritual relationship between the community and its environment. The indicator of natural sacred sites within this category was also rated very highly $(100 \%)$ with a large number of sacred places in the community's natural surroundings. Interviewees consider natural areas as a "good" for all community members and as a sacred gift that all members must take care of.

The traditional management of water and agricultural land and the communitarian conservation of natural resources are evident in the community of Teotitlán del Valle. Water, forest and land voluntary committees have formed within this community to take care of natural resources. These voluntary committees can be considered as valuable stewards for sustainable management at local level. Some "environment and ecology" indicators show a potential for improvement, e.g., in the case of renewable energies; Teotitlán del Valle only has two small solar panels for renewable energy production. A greater use of renewable 
energies could integrate environmental and economic aspects into the community, as suggested in a study by Eckerberg and Mineur (2003). The interviewee's rating of air quality as "very good" was supported by the air quality measurement station, $30 \mathrm{~km}$ west of the study site. No source of air pollution was identified within the study area, except for occasional forest fires.

The "economy" category was rated at a sustainability level of $92 \%$. The production of handcrafted textiles is the main economic activity in the community of Teotitlán del Valle. This activity not only provides an income but is also socially important, since artisans constitute $90 \%$ of the community's production organizations. This has an environmental value since natural dyes and other natural supplies grow on communitarian lands. Textiles are both tangible and intangible elements, as defined by Fagerholm et al. (2012). Finally, the making of handcrafted products involves creativity and self-management, thereby increasing the time dedicated to recreation and to childcare each week, improving overall life satisfaction in the community. Despite the recording of an overall high sustainability level in terms of the "economy," there are cases of chronic malnutrition among children. This was identified as a priority concern in the sustainability assessment. The recognition of unpaid female work by families and society is still only rated at $75 \%$. Furthermore, women are considered as valuable labor in the textile and farming industries within the community, but recognition of their unpaid work is lacking both within families and within society as a whole. The results indicate that competition for well-paid jobs and the dynamics of commercialization are also issues of concern. Since not all producers are paid equally (for example producers of handmade textiles), the competition among community members is increasing and tradesmen tend to benefit the majority, rather than community producers. This situation has led to a constant pursuit of ways to improve sales and production processes in order for producers to obtain a better income.

The "well-being and Buen Vivir" category was rated at a sustainability level of $90 \%$. All the participants were very positive in terms of life satisfaction. Furthermore, the results indicated that there was no social exclusion, which may be attributed to community values. Access to the health service was the only criterion that was rated poorly (50\%). More specifically, participants have suffered pain, discomfort, illness or accidents, preventing them from performing their daily activities during the year and many did not receive appropriate medical attention. Additionally, there are no emergency services available to the community and the nearest hospital is located more than two hours away.

The "education" category was rated at a sustainability level of $86.6 \%$. Schools in the community include the native Zapotec language, and members of the community are involved in the voluntary school committee. However, the average education level (6.9) shows that most of the population only received elementary and secondary-level schooling. There is an absence of higher and professional education institutes close to the community, and young people are encouraged to work with the family from a young age.

Finally, the categories of "population" and "society" were rated lowest in terms of sustainability (80\%) within the assessment. The annual population growth of $0.27 \%$ over the last 10 years in Teotitlán del Valle can be considered rather low. However, this low growth rate mitigates the impact of human activities on the environment. The slow population growth could be attributed to the high rate of emigration (20\%). Inhabitants moving away in the hope of a better income is a growing issue. Furthermore, family planning is also an issue of concern. Only $12 \%$ of females actively plan their family. Readily accessible information on family planning and promotional programs have been suggested to improve this situation. 
Regarding "society," the level of female social participation is 79\%. However, some social issues are apparent, such as criminal activity and fear of violence, which have been gradually increasing. Another "society" issue is the lack of a link connecting the municipality to national and international telecom networks: The population of Teotitlán del Valle does not have access to digital technologies, and the community does not have a telephone line or a mobile telephone signal. Additionally, working children are an issue of concern. There is a fact that many children work, but do not study, may be due to the need for their support to improve family income. Finally, the use of traditional medicine has been decreasing to just $15 \%$ and indigenous knowledge has been decreasing with it. Thus, the protection of community heritage is important to retaining and enhancing the community's sustainability status.

\section{Discussion}

In this discussion, we first evaluate how SAIC values and considerations (left element of Fig. 1) have shaped the analysis. Subsequently, we address selected sustainability outcomes relating to the SAIC method in the community of Teotitlán del Valle, based on the issues relevant for textiles. Finally, we enlist the limitations of our approach and its merits, compared to a Western approach.

\subsection{SAIC values and considerations for integrating indigenous and Western practices}

This study is the first of its kind to integrate ethical dynamics in Mexico that guide the interaction between indigenous and Western participants in a sustainability assessment study. Thus, a collaboration between scientists and indigenous populations in this study, goes beyond previous sustainability assessments in indigenous communities, such as those described by Da Silveira (2005), Yissi and Cartes (2011), Luján-Álvarez et al. (2004), Sancho et al. (2007), Velázquez-Sánchez et al. (2014) and Galván-Martínez et al. (2020).

The values and considerations have placed the indigenous sustainability discourse on an equal level with the Western discourse (Sect. 2.1). The aforementioned detail provides a solution to a problem of connection between knowledge systems and sustainability that Breidlid (2009) highlights. The recognition of both knowledge systems as equal has enabled the creation of a collaborative language within a sustainable assessment method as stated by Muller (2012).

The "sustainability context" has enabled an understanding of the elaboration of handcrafted textiles as the main economic activity of the community. Textiles are tangible elements, referring to the use of products obtained from nature; intangible elements refer to aesthetics, social relations, spiritual, religious and cultural heritage, and traditional knowledge of Teotitlán del Valle. Consequently, we agree with Sae-Wang (2015) that textiles have become cultural commodities and their production is a form of Zapotec intangible heritage, which is important to be safeguarded. Considering the aforementioned points, the analysis of handcrafted textiles (i.e., the main economic activity) has proved useful in developing a solid understanding of the level of sustainability within the community.

The "guiding vision" element of the SAIC integrates indigenous systems, values and spiritual practices. This integration promotes the utilization of valuable indigenous information and experience that were treated as mysticism from a Western perspective as David 
Ludwig (2016) mentioned. In the "guiding vision" element we considered the definitions and the main elements of sustainability of both the Western and the indigenous discourse, positioning them in an equitable and collaborative level as suggested by Muller (2012).

The "essential considerations" elements included "otherness" and allowed us to address indigenous practices, such as traditional food production and health systems along with Western sustainability practices in the form of indicators. Overall, following the SAIC, the essential considerations (Fig. 1) allowed us to establish collaboration with the indigenous community and promote participation through an intercultural and equal dialog during feedback sessions. The community "adequate scope" was considered appropriate and could possibly be useful at local level for non-indigenous communities.

In terms of "transparency" and the "broad participation of stakeholders," we agreed with Ander-Egg (2003) that participatory guidelines allow community members to be a decisive and fundamental factor within the research.

\subsection{SAIC procedure for assessing sustainability in Teotitlán del Valle}

By applying the SAIC method, it was possible to include disparate types of knowledge in the sustainability conversation, as suggested by Sterling (2017). Hence, the SAIC method is a functional and constructive method for creating a synergy across Western and indigenous knowledge systems for indigenous communities. The SAIC method responds to a need among indigenous communities for an assessment method (Tengö et al., 2014).

The community's main sustainability issues are related to access to health care, gender equality, education, migration and preservation of the native language. Our results concerning access to health care are not in line with the findings of Leyva-Flores et al. (2013) who report appropriate governmental health coverage in Mexico, as there are no medical services available in Teotitlán del Valle. Fieldwork showed that many indigenous communities close to the study area are also in a similar situation. By comparison, in Oaxaca city, healthcare coverage may be different for indigenous and non-indigenous inhabitants.

The number of women working in the labor market is high. However, the recognition of unpaid work is low. Similarly, gender equality not only depends on the labor market but also on the recognition of unpaid work by both the family and society as a whole (Yissi and Cartes 2011). It is necessary to follow strategies to promote the recognition of unpaid female work. The results relating to "education" concur with those of Yissi and Cartes (2011). Education levels are lower in rural communities than in the city. According to UNICEF, those who live in indigenous communities are particularly at risk of not going to school. According to the Economic Commission for Latin America and the Caribbean (CEPAL), this phenomenon can be attributed to: the structural discrimination of indigenous communities, difficulties in accessing education (due to deficient infrastructure); insufficient, culturally appropriate educational policies and a lack of mechanisms for the effective participation of communities in teaching and learning projects. Regarding migration, our results differ from Yissi and Cartes (2011) who found that young people form the main migrant group.

We found high levels of participation in traditional events, concur with the results from Yissi and Cartes (2011), who regard high participation levels as a characteristic of indigenous communities, since the promotion of participation is linked to the success of improvement programs. In line with Luján-Álvarez et al. (2004), respect and care for community life favors the encouragement of sustainable development and a better quality of life. Del Popolo and Schkolnik (2005) mention that an indication of the loss of language constitutes 
the proportion of young speakers compared to adult speakers. These authors mention that the loss of local languages might be due to the pressure and influence of global society. Since the loss of the native language is linked to cultural identity, we suggest considering necessary measures for its preservation.

\subsection{SAIC indicators for bridging indigenous and Western sustainability discourses}

Compared to traditional index systems, the proposed one allows assessing family dynamics, gender and territorial dynamics by means of indicators at an appropriate local scale. Furthermore, in contrast to most traditional systems it considers traditional systems, community values and indigenous culture and identity. Thus, it opens a common ground between Western and Indigenous sustainability discourses to address local and community practices from both perspectives.

The SAIC set of indicators increase the indicators used in previous studies for indigenous communities (Galván-Martínez et al., 2020). The proposed set of indicators is capable of assessing essential aspects such as waste management, air quality, water management issues, communitarian values, family dynamics and community network, the income gap between men and women, social exclusion and family planning among others.

From a Western sustainability perspective, spiritual aspects would not have been considered within the category of "environment and ecology." The connection between sacred natural places and high sustainability concurs with Simpson (2000), who reaffirmed that indigenous communities tend to maintain a harmony with their environment which can be ascribed to their community values and spirituality. For the community of Teotitlán del Valle, caring for the environment is conditioned by spirituality which evokes the need to conserve resources within the community. The spiritual natural sites indicator is congruent with Raymond et al. (2010), who argue that communitarian values, spiritual use and norms of natural sites improve their management.

Traditional medicine, governmental systems and food production systems would also not be considered in Western-based assessments. Since part of the identity of the community of Teotitlán del Valle lies in its traditional systems, the combined approach chosen for this assessment is considered particularly suitable. Sustainable traditional systems can inform urgent issues in Western discourse, such as the world food program's aim for "Zero hunger," responsible food consumption and production of food, sustainable economic growth, as well as reduced greenhouse gas emissions and a reduction in waste. Traditional, sustainable systems may provide good examples of sustainable practices at local level.

We noted that Western sustainability indicators can provide specific value when monitoring a community's sustainability status. Environmental indicators such as "percentage of forest loss." "days of satisfactory air quality" and "rate of municipal wastewater treatment" are traditionally not traditionally considered in the indigenous sustainability discourse, but they support the assessment of the degradation of natural resources. Western indicators to measure economic dynamics at local level, such as "local employment" and the "incorporation of women in the labor market," helped to establish women in the labor market in our case study, despite the prevalence of unpaid work. Overall, the indicators rooted in Western discourse have proven useful in contributing to the identification of the strengths and weaknesses of local sustainability.

While we found the literature-based indicators set effective, the interaction with the local community leads us to propose to develop indicators to measure the interaction of local spirituality and environment dynamics. Such indicators should go beyond the evaluation of 
the existence of spiritual practices such as rituals but also assess the importance of these practices for local sustainability. Specifically, the indicators "Level of importance of spiritual beliefs in caring for natural resources" and "Level of impact of spirituality on social/ economic aspects" are suggested.

\subsection{Implications of the SAIC method}

The practical implications of this work consist of the use of the results to set actions according to the main sustainability issues. Data obtained allow decision-makers to set the guidelines for actions in order to improve sustainability; access to health services and family planning received the lowest scores in questionnaires. The researchers recommend, based on the evidence, that is feasible to send a petition to the government with the aim of implementing proper health services. Participative workshops and projects focused on traditional medicine should be established though national or international networks. Participative working networks would encourage the establishment of workshops addressing family issues and the social recognition of unpaid work in order to enhance woman empowerment.

In the future, we aim to apply this method in other Zapotec indigenous communities. There are around 100 Zapotec indigenous communities in the central valleys of Oaxaca with apparently similar characteristics. First, we would like to see if the results found in this study are typical for Zapotec indigenous communities. Second, we would like to compare the sustainability of Zapotec indigenous communities with the sustainability of other indigenous communities in and out of Mexico. Third, this method could be useful in assessing sustainability at local level in non-indigenous communities.

\subsection{Limitations of the SAIC method}

Even when this method is flexible in relation to data availability, it was found that the use of quantitative indicators allows the efficient comparison of different study cases. In our study, due to a lack of governmental information, questionnaires had to be used in order to gather certain data. However similar difficulties have been observed by other authors (Lu et al., 2017; Sowińska-Świerkosz, 2017), who state that data collection in local assessments can be challenging. Facing the corresponding data availability issues, is a usual situation (Seingier et al., 2020). We agree with Seingier et al. (2020) that every study case will deal with minor adjustments. Furthermore, some indicators measure complex cultural and social aspects and would benefit from further qualitative research to clarify their underlying concepts. In such situation, we provide potential sources (primary data and secondary data) within the indicator set, which must be specified when applying this method. This points to the importance of availability of sustainability data for every study case.

We agree with Sowińska-Świerkosz (2017) that assessing cultural aspects can be challenging in order to represent the results in a quantitative way. Cultural aspects such as indigenous pride, the level of participation in the community and identity, require qualitative details in order to understand them comprehensively. To address this, the method includes six cultural and identity indicators including feeling proud of being indigenous, speaking the native language, community participation in religious and cultural events, ceremonies and traditional festivals. These kinds of aspects have not been assessed in previous studies. In this sense, we find that the use of only qualitative techniques restricts the application of the methods within the communities themselves. Qualitative techniques such as 
content analysis can be time-consuming (Sowińska-Świerkosz, 2017) and require an additional qualification on the part of the stakeholders in structuring the questions and carrying out analysis.

Another limitation of this study relies on its applicability to other communities. As Sterling et al. (2017) mention, criteria among indigenous communities do not have to be exactly the same. The application of the method in the study area was adequate; nevertheless, it might not be suitable for other areas. This method and its indicators should be validated in other indigenous communities, addressing specific local contexts (Sterling et al. 2017), although the sustainability context should be considered through participatory dynamics, such as feedback sessions and indicator adjustments to determine future action.

\section{Conclusions}

This study developed a sustainability assessment method for indigenous communities and applied it by assessing the sustainability of Teotitlán del Valle, an indigenous community in Mexico. The method integrates Western and indigenous sustainability discourses, within an indigenous context and scale. We used an integrated set of sustainability indicators (in total 55 indicators), including both Western and indigenous sustainability indicators; Western indicators were adapted to indigenous contexts and particularities. Our set of indicators thus contributes new perspectives to previous research, by aiming to comprehensively address sustainability issues.

In the study area, "democracy and governance" gets the highest ratings. Indeed identity and community practices enhance sustainability in the study area, as participation of people in the management of their territories can increase the sense of care for their environment and resources. Thus, these aspects provide opportunities to strengthen sustainability in indigenous and non-indigenous communities. The assessment results of the present work showed that health services and family planning received the lowest scores. Additionally, we found relatively low values in relation to indigenous people speaking their native language, links to national or international networks, the use of traditional medicine, family and social recognition of unpaid work and the use of renewable energies.

The proposed method can be seen as a starting point for sustainability assessments in indigenous communities. Its particular strength lies in the fact that the research interaction between indigenous stakeholders and scientists is reframed in an assessment method, capable of considering the context and knowledge system from the perspective of everyone. It is thus a flexible method for indigenous communities, and the results yielded can be compared over time to analyze trends of sustainability footprints. The SAIC method is well suited to being applied by the community itself in future because it relies on local interviews and widely available statistical data, promoting indigenous self-sufficiency and sovereignty.

In addition, the SAIC method has provided a hint in relation to the direction toward which development is heading, and has proved helpful in predicting social and ecological implications. The issues identified can be used as guidelines for decision-making in future regional projects and development plans. 


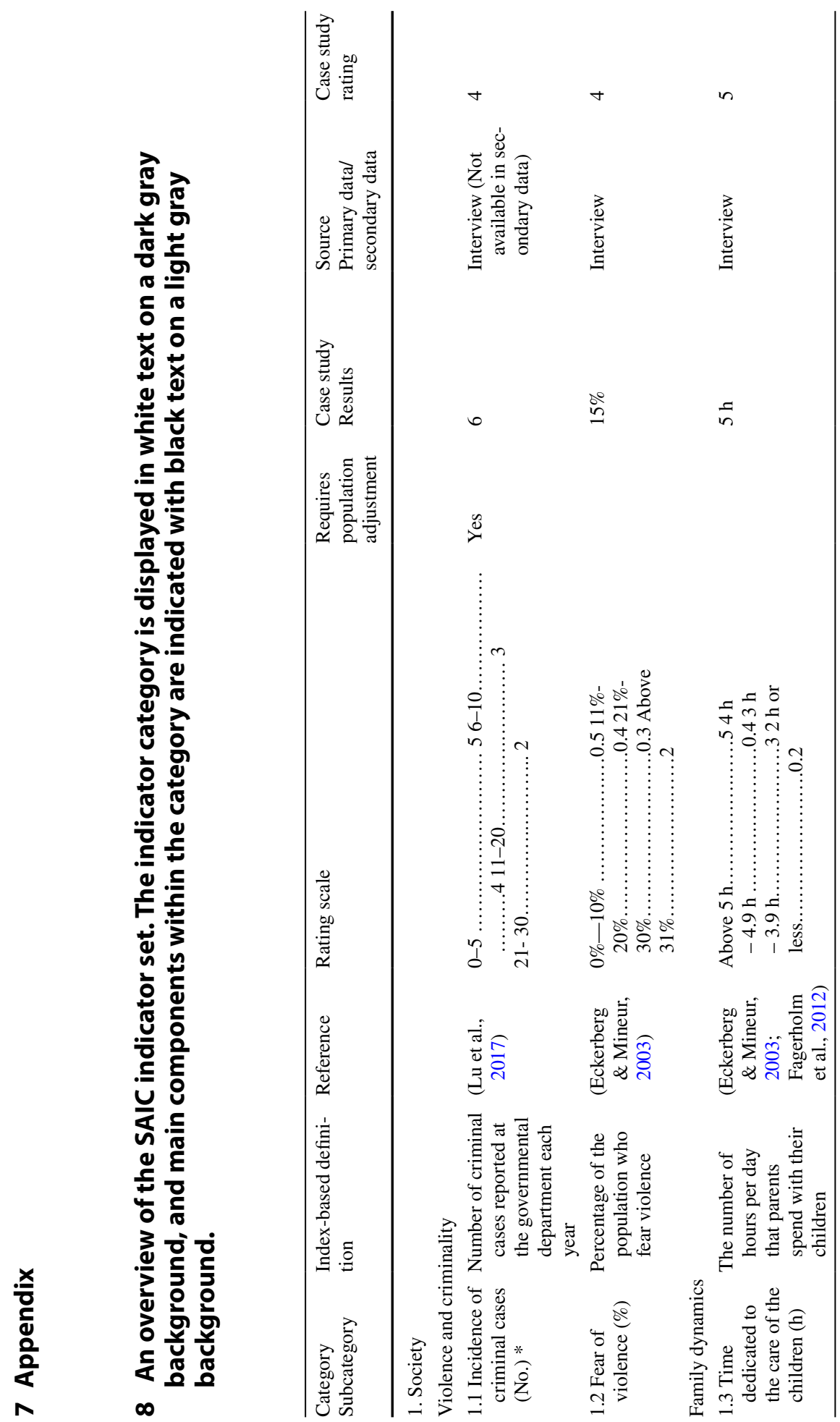




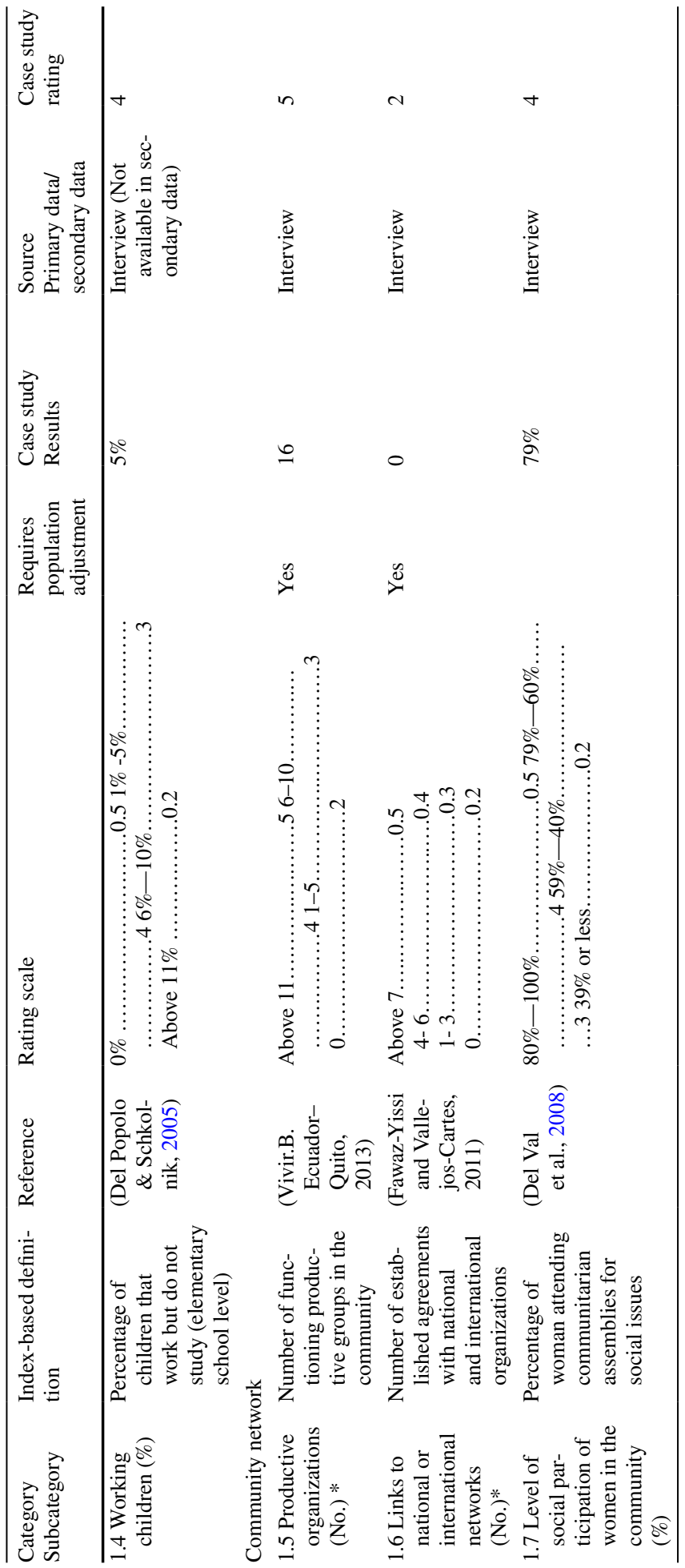

Springer 


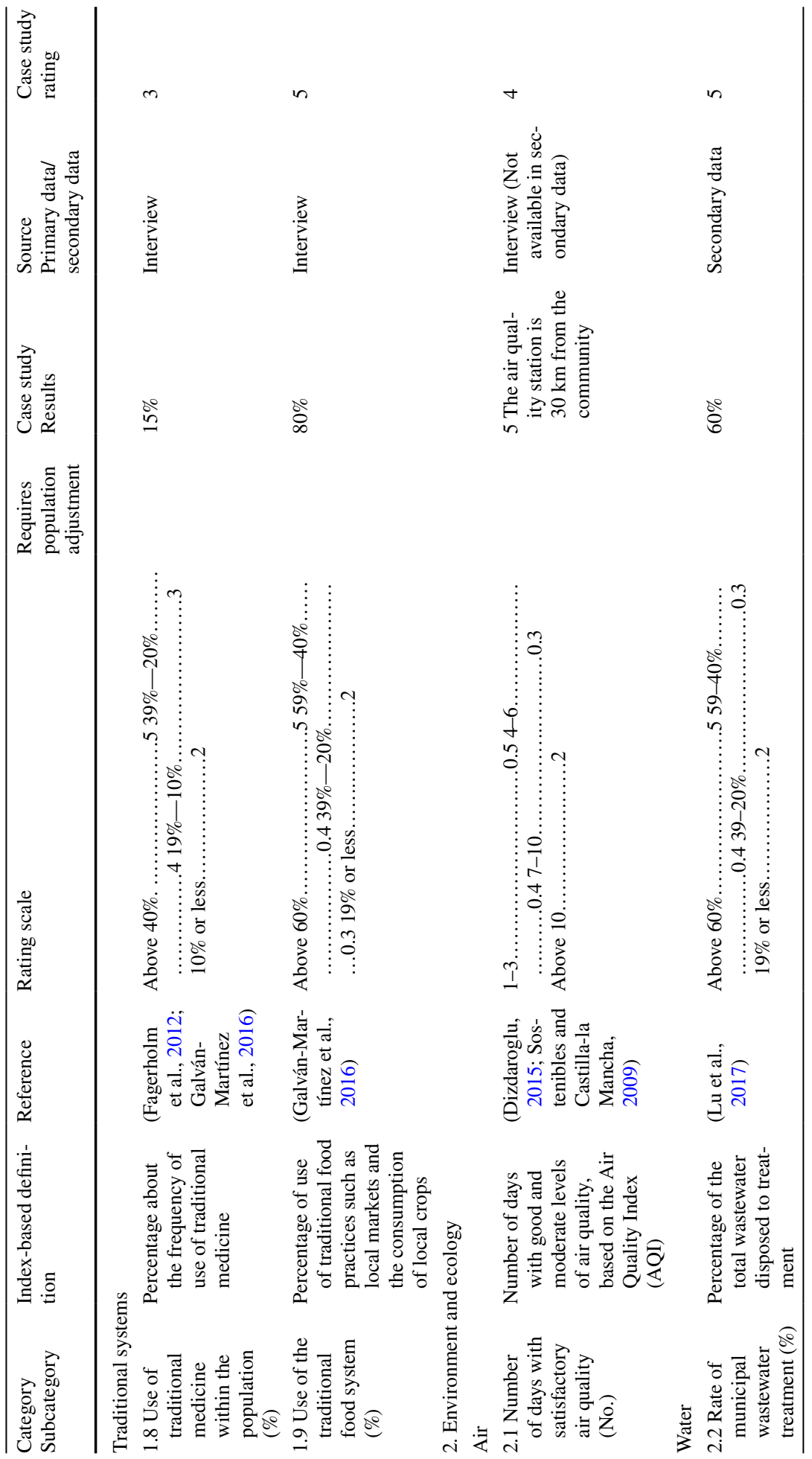




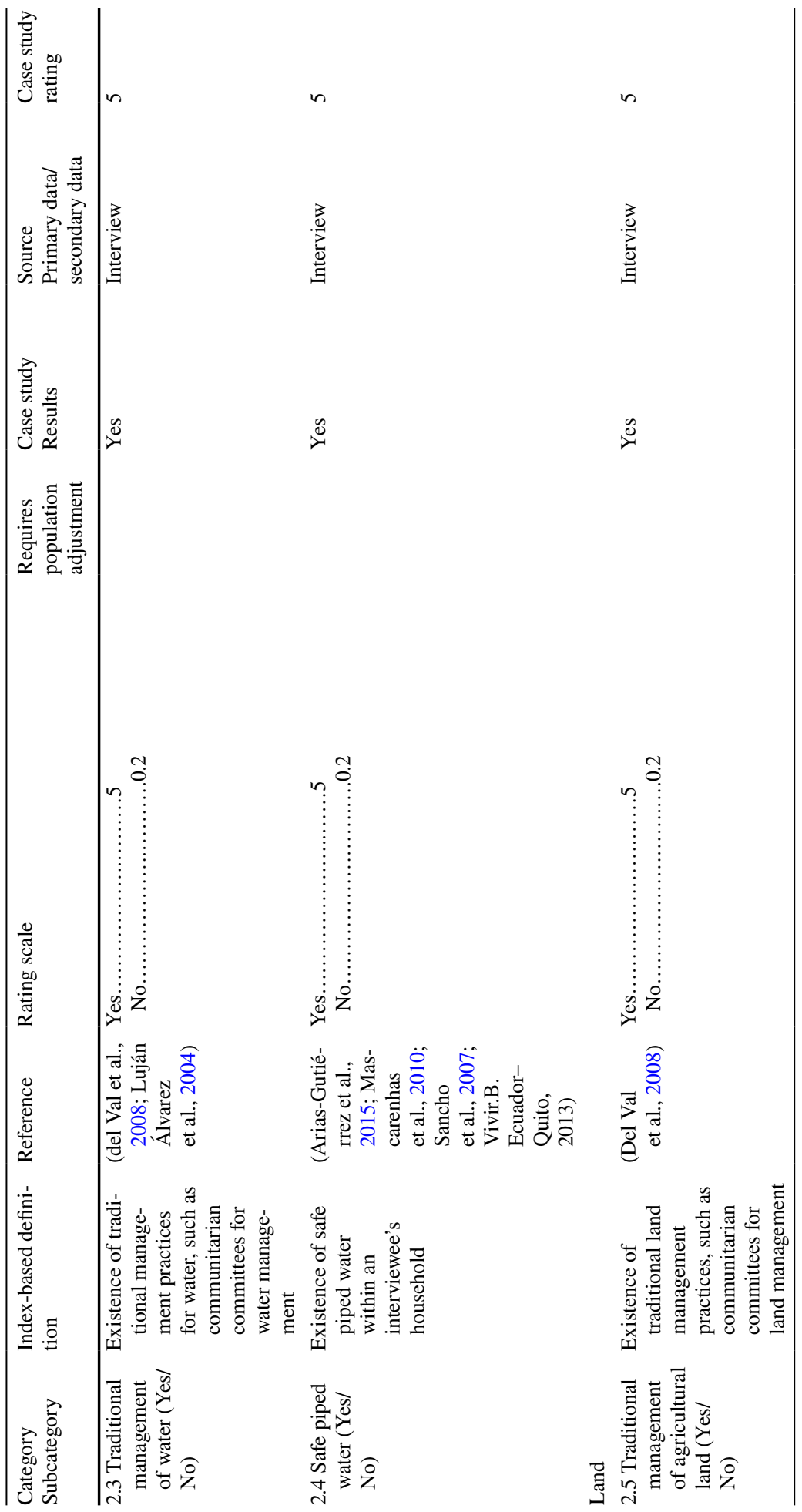

Springer 


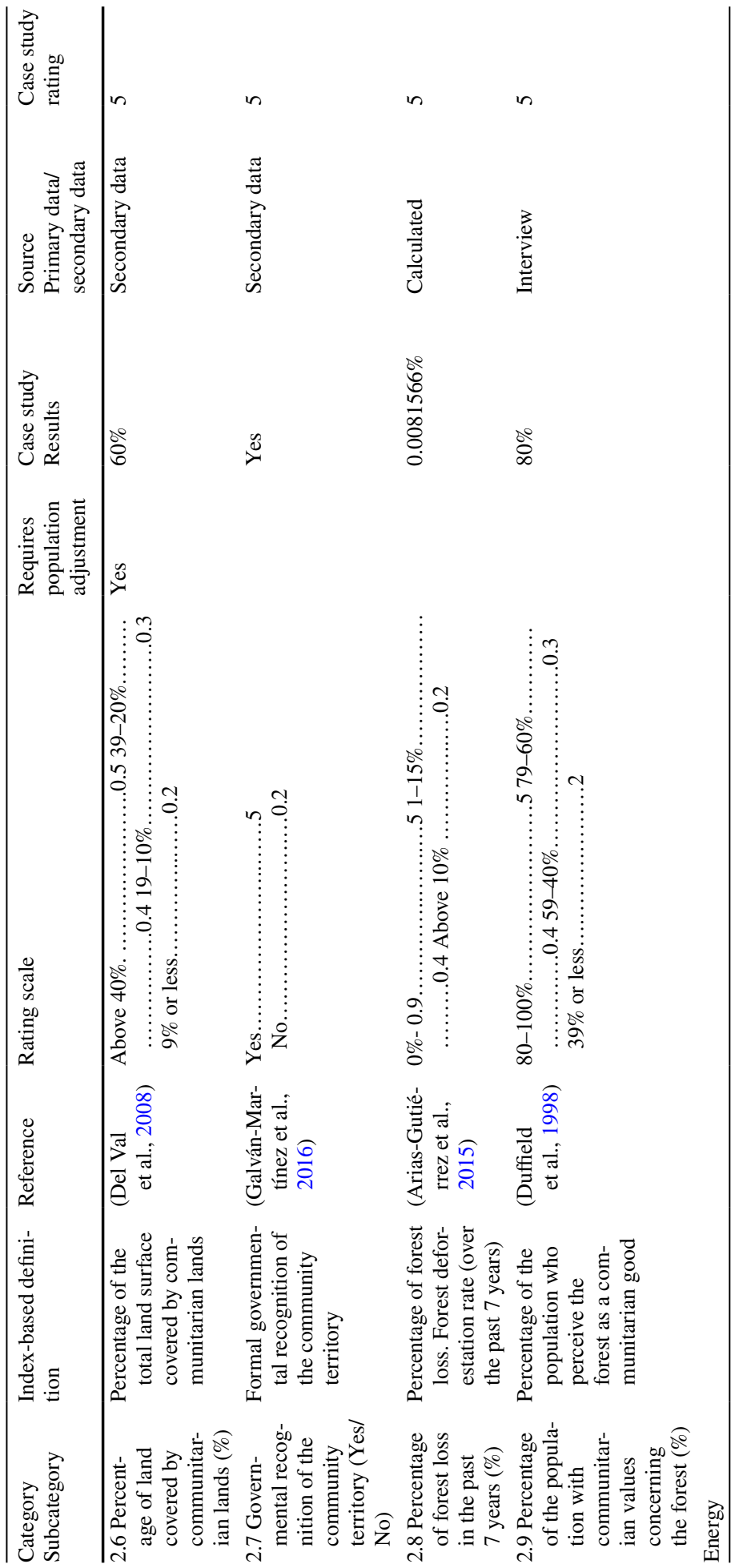




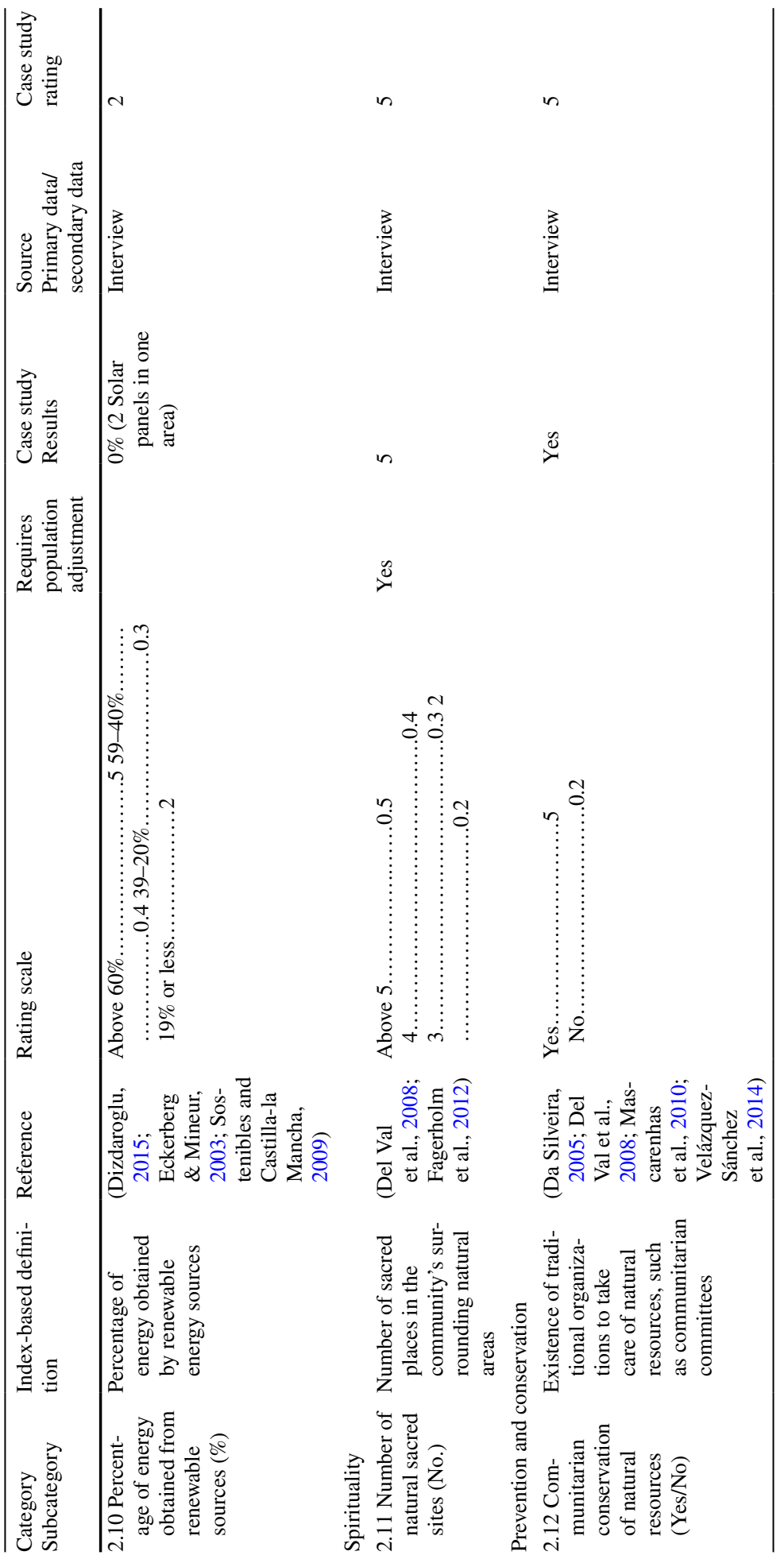

Springer 


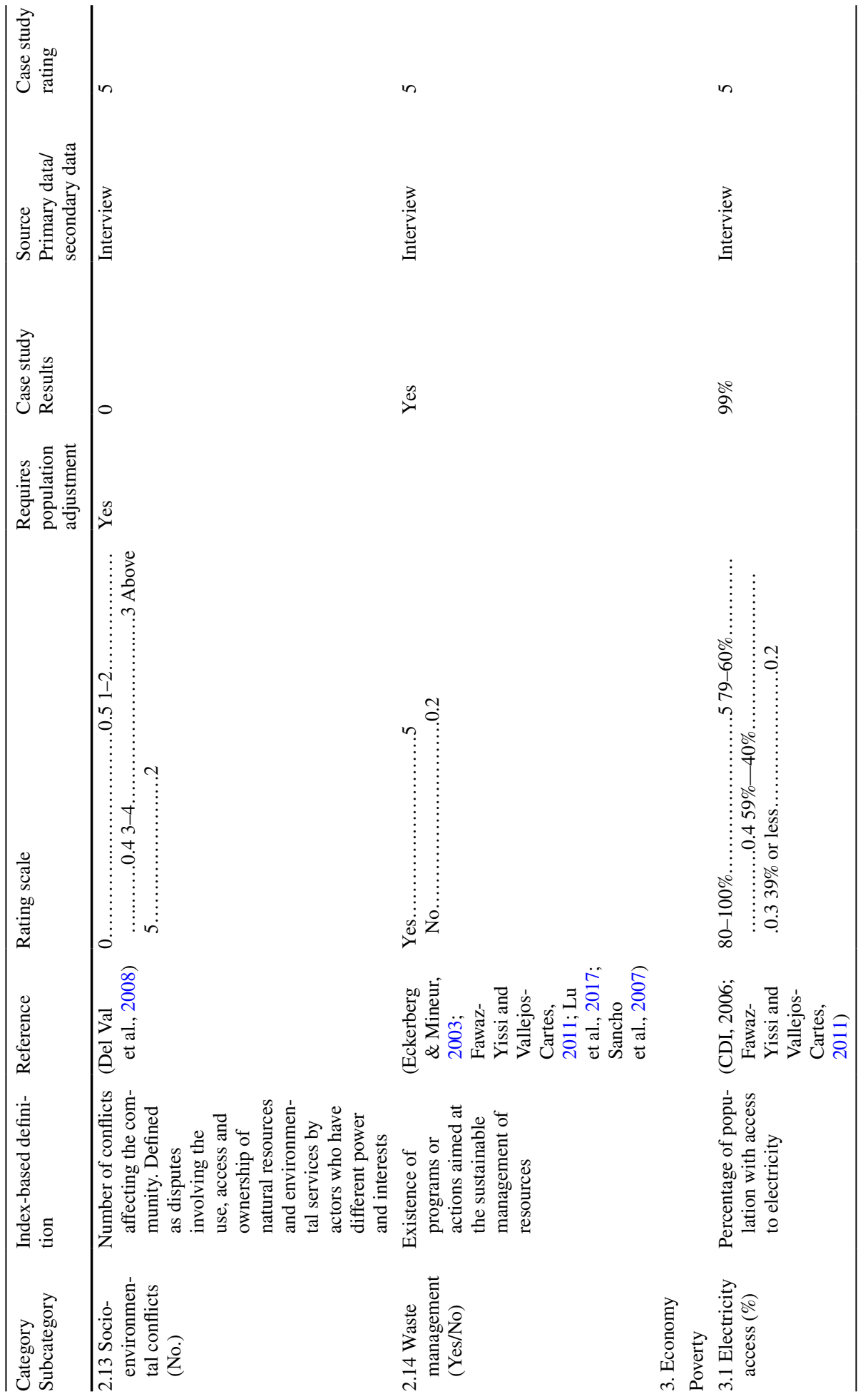




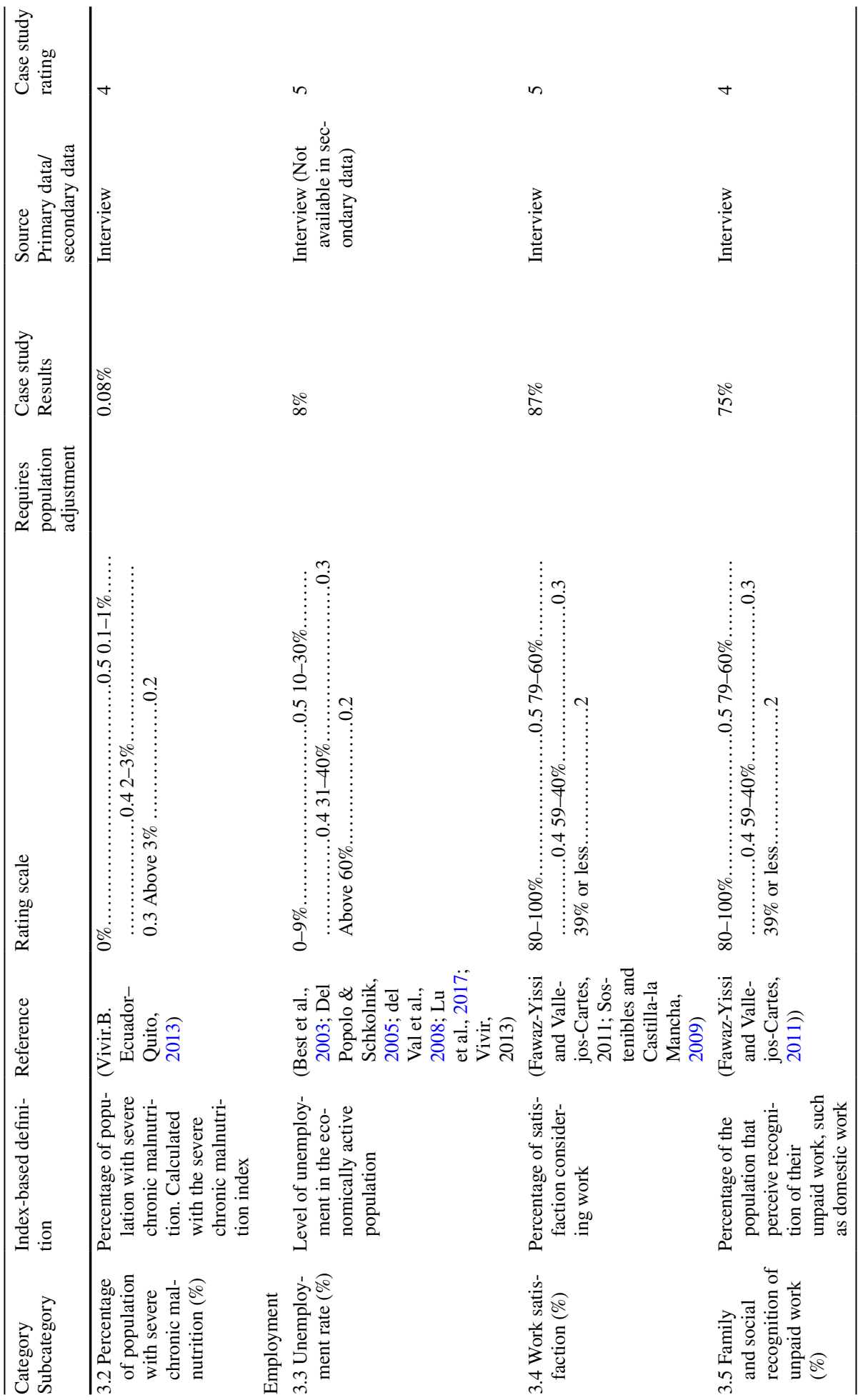




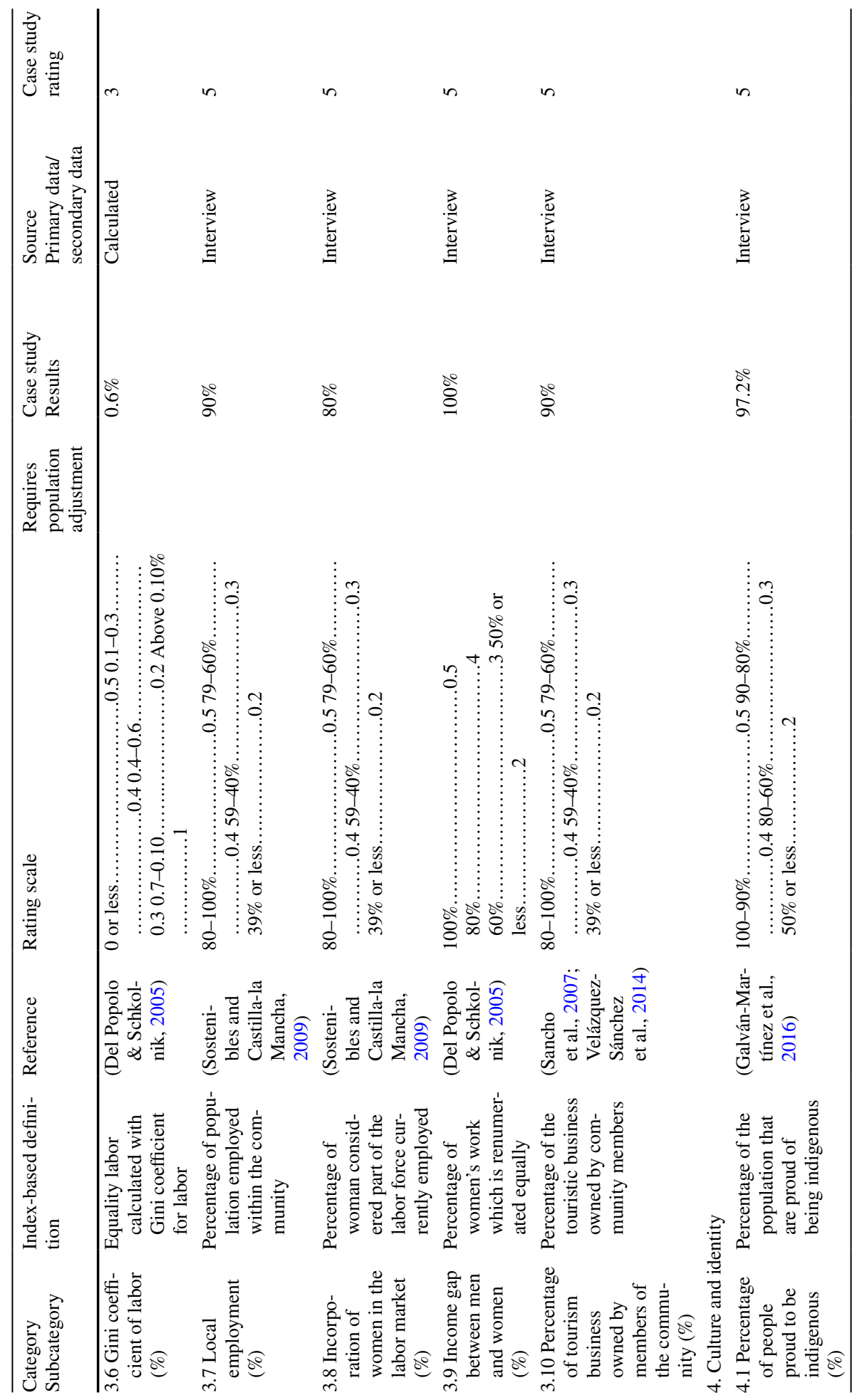




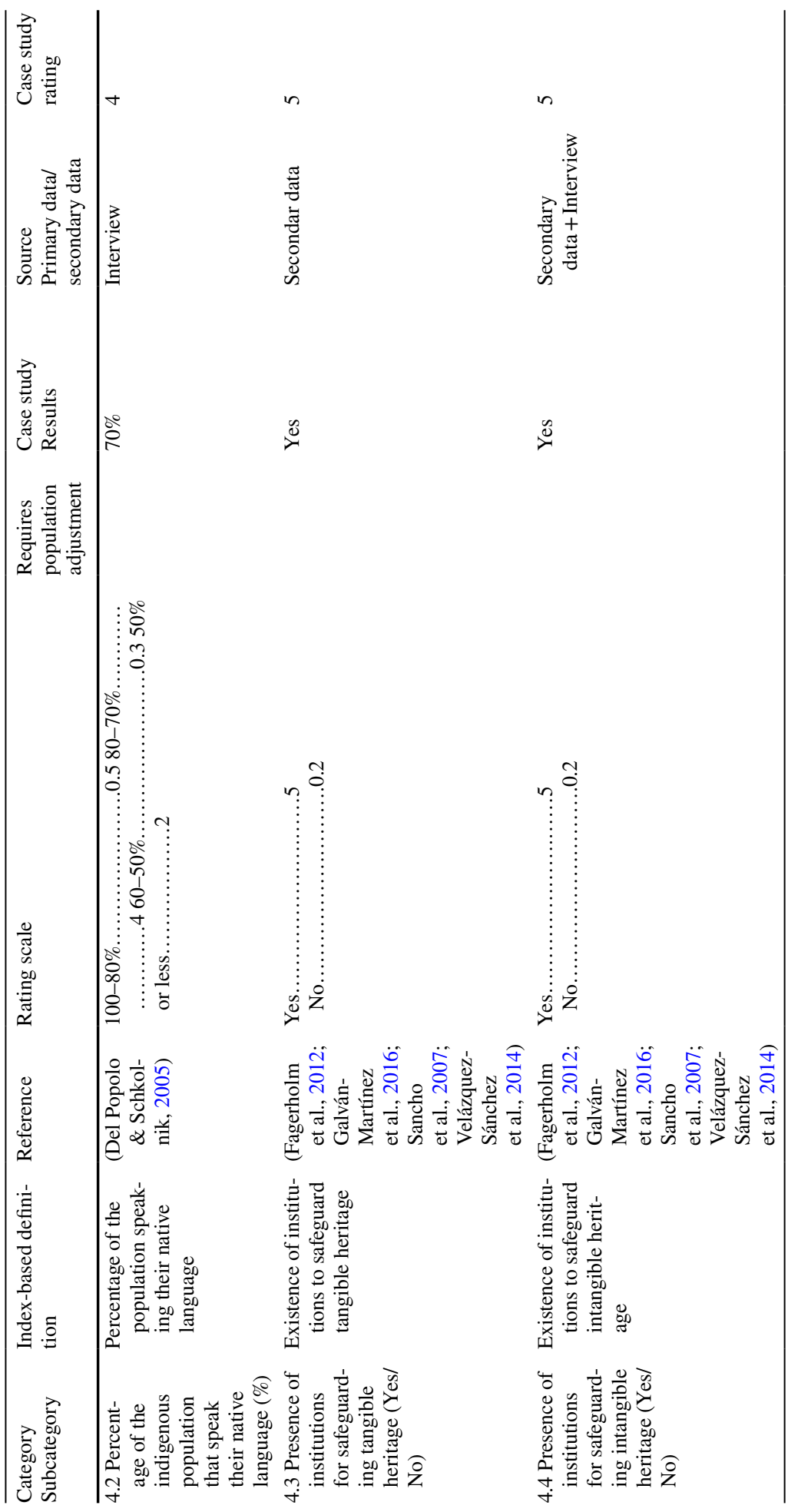




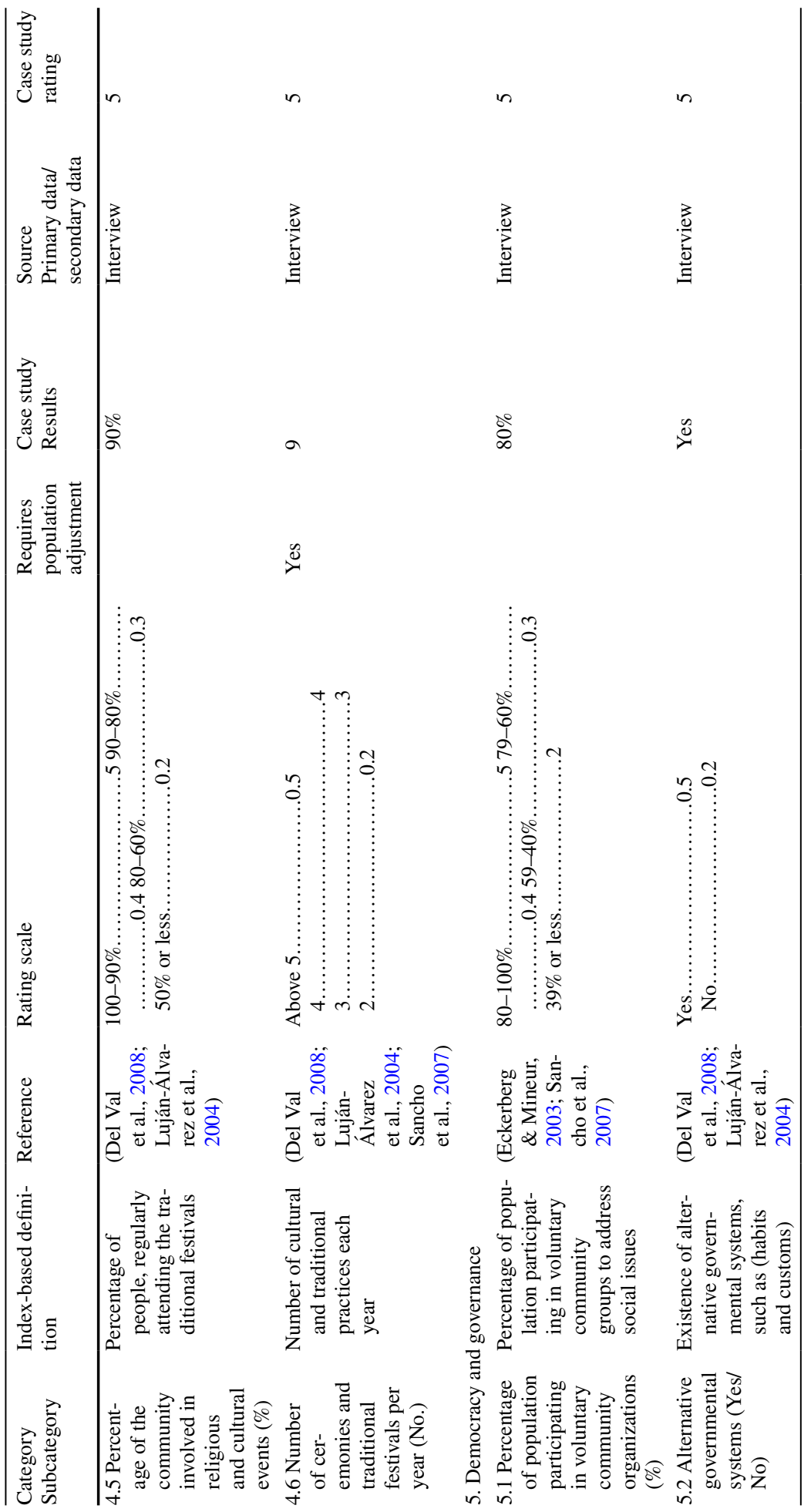




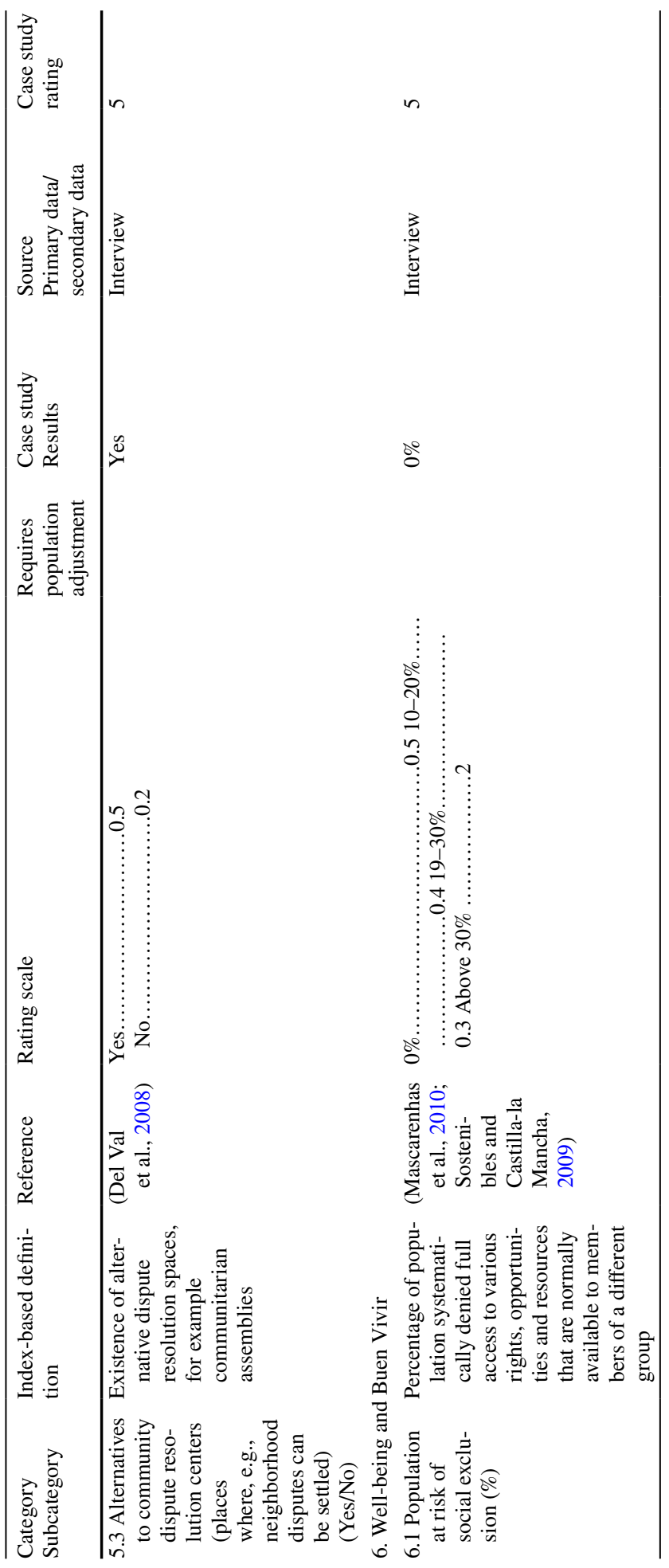

Springer 


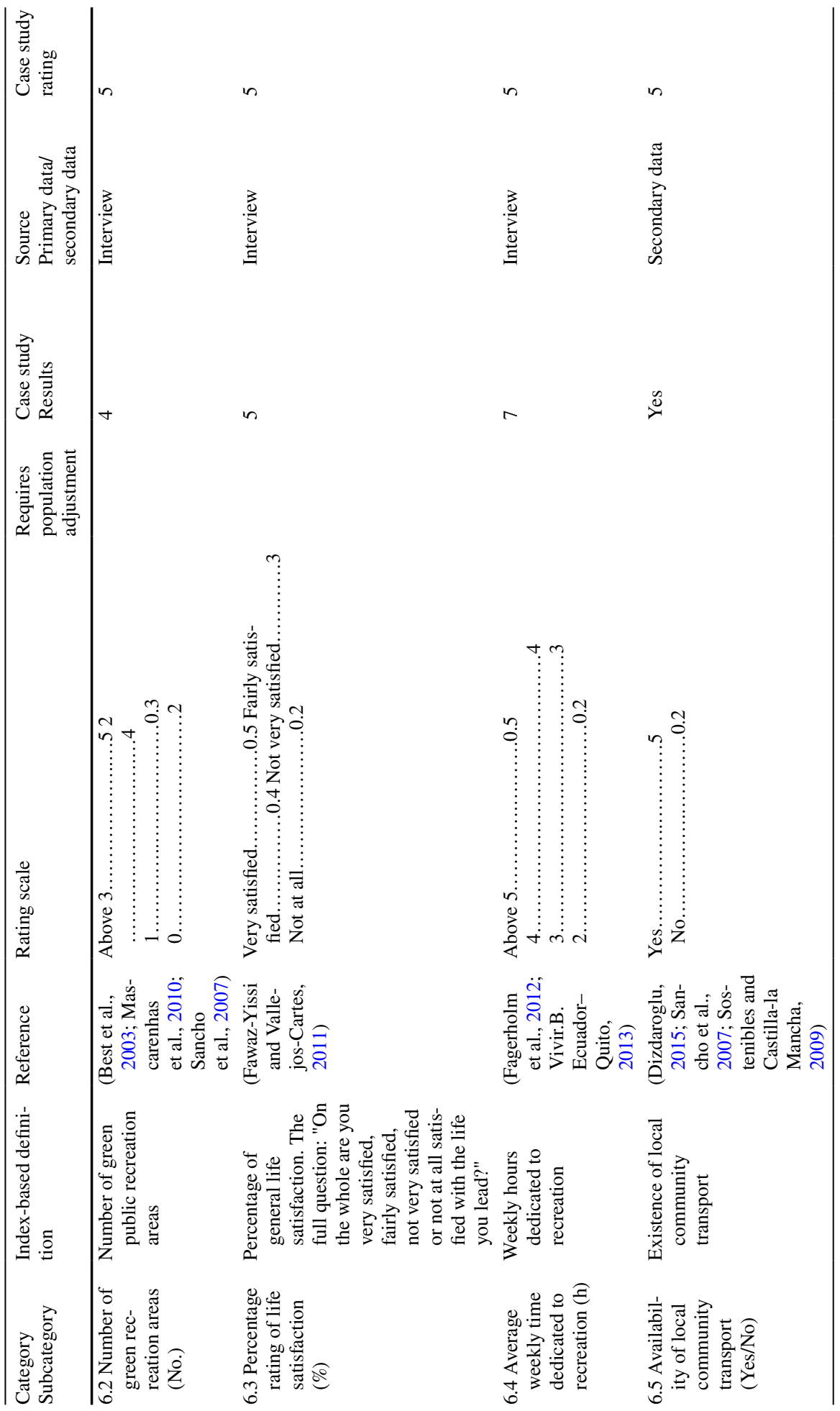




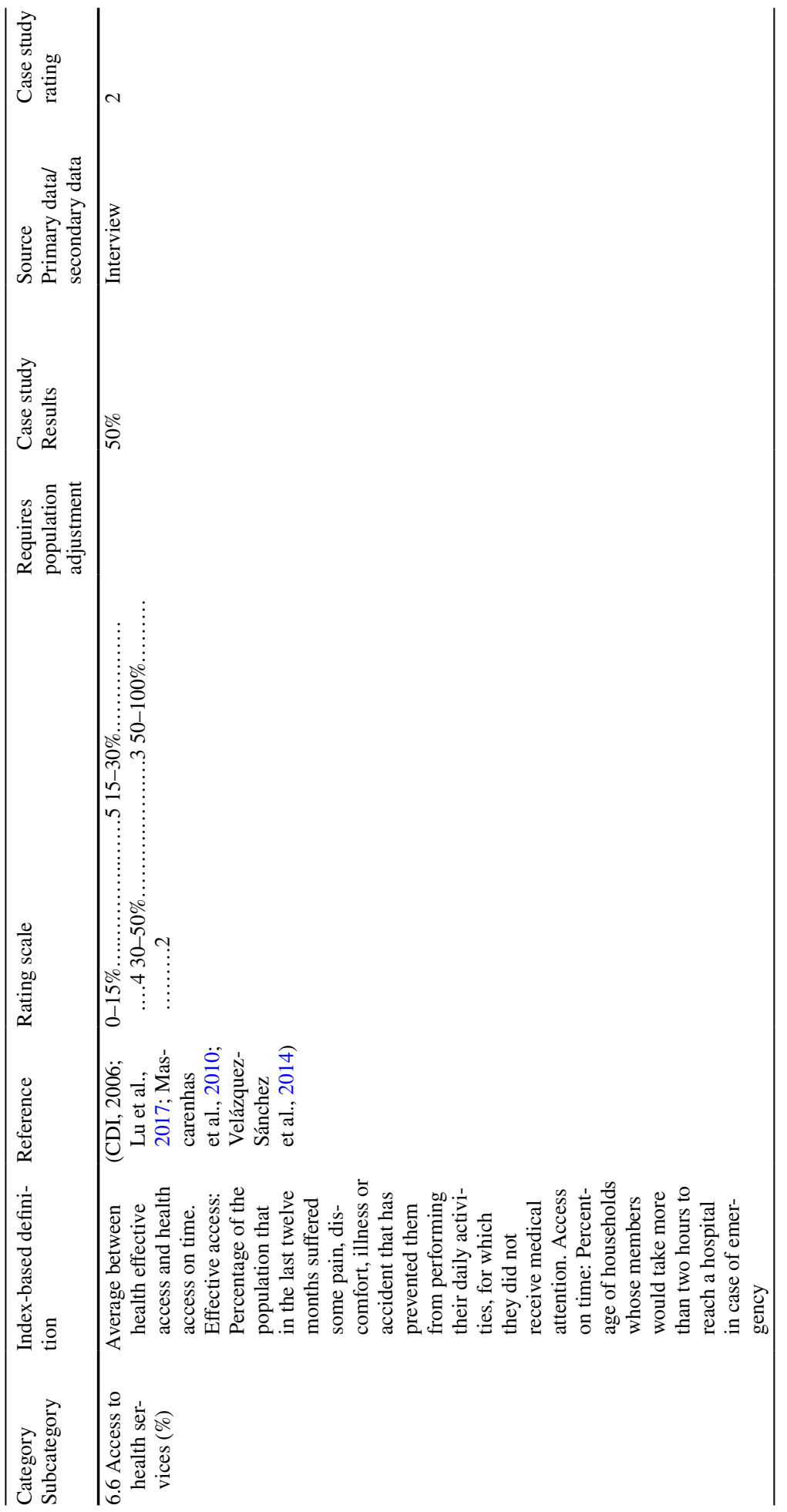

Springer 


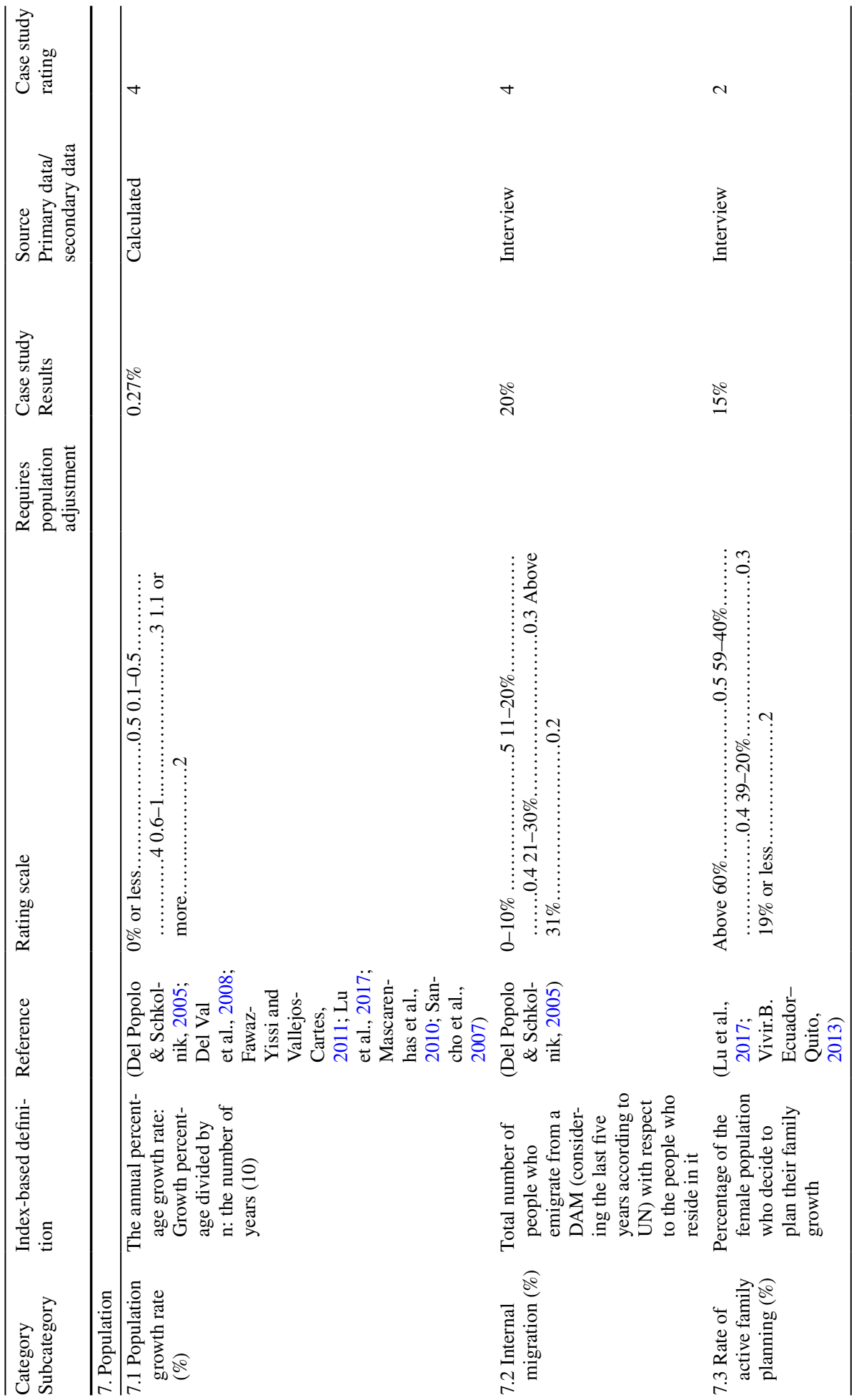




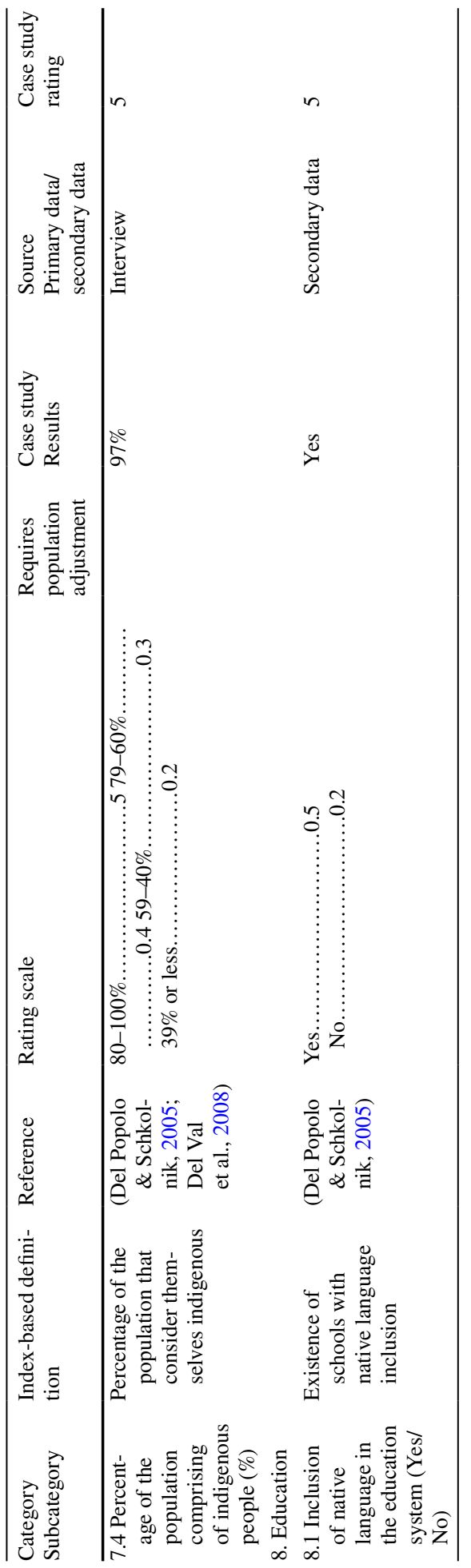

Springer 


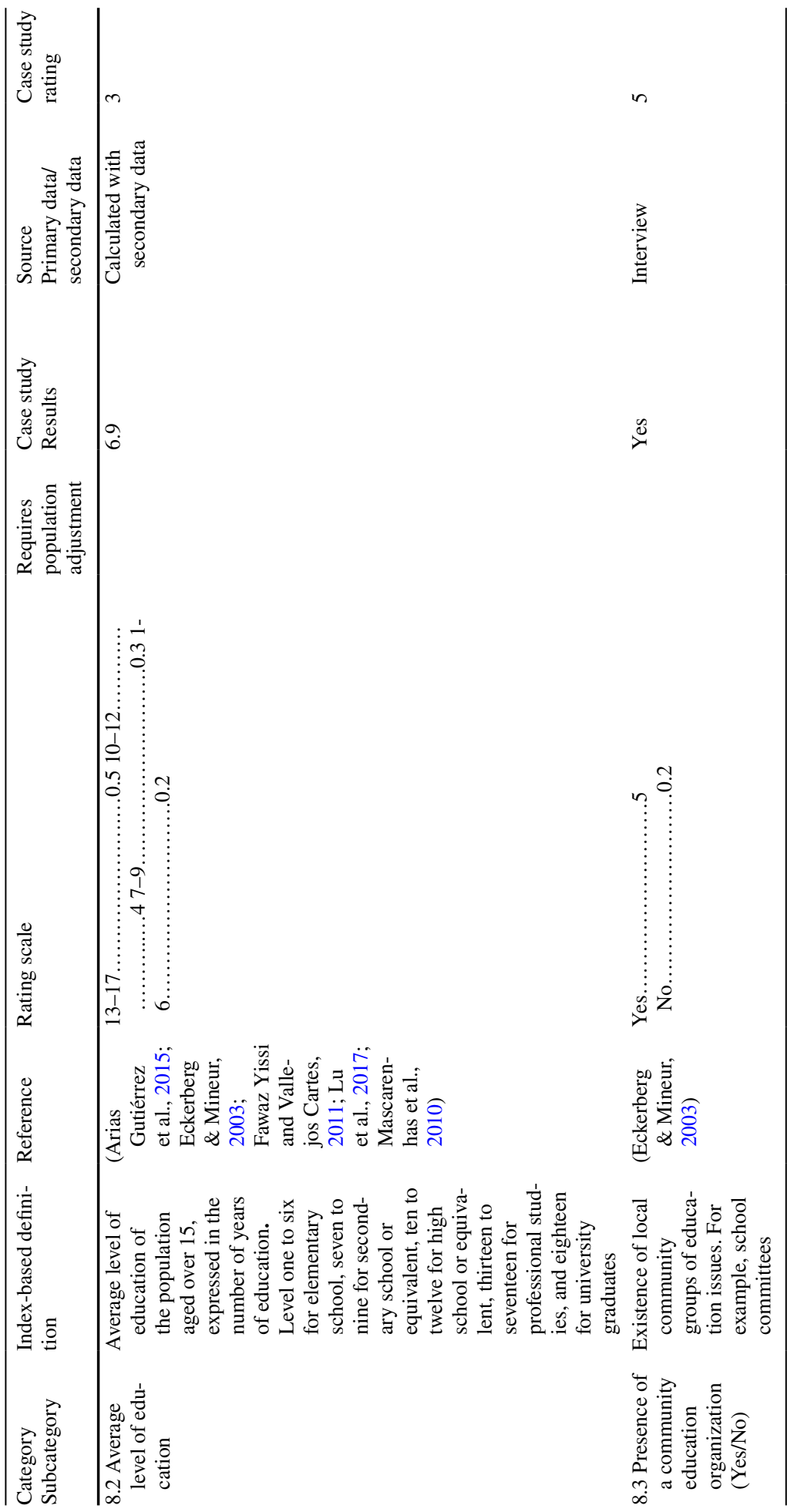


Acknowledgements The authors express their gratitude to the Consejo Nacional de Ciencia y Tecnología (CONACYT), Mexico, for making possible the present research funding for the $\mathrm{PhD}$ studies that frame it. We would like to thank the inhabitants of Teotitlán del Valle for their participation in this research and Sara Sarah Radford for providing English language corrections.

Funding Open Access funding provided by Lib4RI - Library for the Research Institutes within the ETH Domain: Eawag, Empa, PSI \& WSL.

Open Access This article is licensed under a Creative Commons Attribution 4.0 International License, which permits use, sharing, adaptation, distribution and reproduction in any medium or format, as long as you give appropriate credit to the original author(s) and the source, provide a link to the Creative Commons licence, and indicate if changes were made. The images or other third party material in this article are included in the article's Creative Commons licence, unless indicated otherwise in a credit line to the material. If material is not included in the article's Creative Commons licence and your intended use is not permitted by statutory regulation or exceeds the permitted use, you will need to obtain permission directly from the copyright holder. To view a copy of this licence, visit http://creativecommons.org/licenses/by/4.0/.

\section{References}

Agrawal, A. (1995). Dismantling the divide between indigenous and scientific knowledge. Development and Change, 26, 413-439.

Ander-Egg, E. (2003). Repensando la Investigación-Acción Participativa. Lumen-Humanitas.

Arias Gutierrez, R. I., Gonzalez Sousa, R., Herrera Sorzano, A., \& Aleman Perez, R. D. (2015). Comprehensive assessment of Kichwa Ecuadorian Amazon communities for the elaboration of the strategy for sustainable development. II. Socioeconomic Indicators. Centro Agricola, 42(3), 75-81.

Australian Institute of Aboriginal and Torres Strait Islander Studies (AIATSIS). (2011). Guidelines for ethical research in Australian Indigenous studies. Australian Institute of Aboriginal and Torres Strait Islander Studies. https://aiatsis.gov.au/research/ethical-research.

Best, A., Conlin, R., Palmer, K., Crofut, S., Hatcher, L., Roberts, J., Tuttle, C., Walter, S. (2003). Indicators of Sustainable Community. Sustainable Seattle. https://ise.unige.ch/isdd/IMG/pdf/Indicateurs.pdf

Bond, A. J., \& Morrison-Saunders, A. (2011). Re-evaluating sustainability assessment: Aligning the vision and the practice. Environmental Impact Assessment Review, 31, 1-7.

Bozigar, M., Gray, C. L., \& Bilsborrow, R. E. (2016). Oil Extraction and indigenous livelihoods in the northern Ecuadorian amazon. World Development, 78, 125-135.

Breidlid, A. (2009). Culture, indigenous knowledge systems and sustainable development: A critical view of education in an African context. International Journal of Educational Development, 29, 140-148.

Brundtland, G. H. (1989). Global change and our common future. Environment, 31, 16-43.

Calleros-Islas, A. (2019). Sustainability assessment. An adaptive low-input tool applied to the management of agroecosystems in México. Ecological Indicators, 105, 386-397.

CELADE. (2012). Sistema de Indicadores Sociodemográficos de Poblaciones y Pueblos Indígenas (SISPPI) 1-54. https://celade.cepal.org/redatam/PRYESP/SISPPI/Webhelp/helpsispi.htm

Choi, H. S. C., \& Sirakaya, E. (2006). Sustainability indicators for managing community tourism. Tourism Management, 27, 1274-1289.

Clark, W. C., \& Dickson, N. M. (2003). Sustainability science: The emerging research program. Proceedings of the National Academy of Sciences, 100, 8059-8061.

da Silveira, M. A. T. (2005). Turismo y sustentabilidad. Entre el discurso y la acción. Estudios y Perspectivas En Turismo, 14(3), 222-242.

de Oliveira, R. K., Higa, A. R., Silva, L. D., Silva, I. C., \& da Penha Moreira Gonçalves, M. . (2018). Emergy-based sustainability assessment of a loblolly pine (Pinus taeda) production system in southern Brazil. Ecological Indicators, 93, 481-489.

Del Popolo, F., \& Schkolnik, S. (2005). Los censos y los pueblos indígenas en América Latina: Una metodología regional. Notas De Población, 31(79), 101-132.

Del Val, J., Rodríguez, N.J., Rubio, M.A., Sánchez G., C., Zolla, C. (2008). Los pueblos indígenas y los indicadores de bienestar y desarrollo "Pacto del Pedregal", 184. https://red.pucp.edu.pe/ridei/files/ 2011/08/381.pdf.

Desa, U.N. (2016). Transforming our world: The 2030 agenda for sustainable development. https://stgwe docs.unep.org/bitstream/handle/20.500.11822/11125/unepswiosm1 inf7sdg.pdf?sequence=1. 
Díaz, J. H. (2012). La danza de la pluma en Teotitlán del Valle: expresión de identidad de una comunidad zapoteca. Secretaría de las Culturas y Artes de Oaxaca.

Dizdaroglu, D. (2015). Developing micro-level urban ecosystem indicators for sustainability assessment. Environ. Environmental Impact Assessment Review, 54, 119-124.

Duffield, C., Gardner, J. S., Berkes, F., \& Singh, R. B. (1998). Local knowledge in the assessment of resource sustainability: Case studies in Himachal Pradesh, India, and British Columbia. Canada. Mountain Research and Development, 18, 35.

Eckerberg, K., \& Mineur, E. (2003). The use of local sustainability indicators: Case studies in two Swedish municipalities. Local Environment, 8, 591-614.

Fagerholm, N., Käyhkö, N., Ndumbaro, F., \& Khamis, M. (2012). Community stakeholders' knowledge in landscape assessments - Mapping indicators for landscape services. Ecological Indicators, 18, 421-433.

Galván-Martínez, D., Almada, F., \& J.L., Espejel, I. . (2016). ¿Sustentabilidad comunitaria indígena? Un modelo integral indigenous community sustainability? An integral model. Sociedad y Ambiente, 11, 4-22.

Galván-Martínez, D., Espejel, I., Arredondo-García, M. C., Delgado-Ramírez, C., Vázquez-León, C., Hernández, A., \& Gutiérrez, C. (2020). Sustainability Assessment in Indigenous Communities: A Tool for Future Participatory Decision Making. In Stewardship of Future Drylands and Climate Change in the Global South (pp. 197-214). Cham: Springer.

Gudynas, E. (2011). Buen vivir: Germinando alternativas al desarrollo. América Latina en movimiento, 462, $1-20$.

Hart, M. A. (2010). Indigenous worldviews, knowledge, and research: The development of an indigenous research paradigm. Journal of Indigenous Social Development, 1(1A).

Holzer, J. M., Carmon, N., \& Orenstein, D. E. (2018). A methodology for evaluating transdisciplinary research on coupled socio-ecological systems. Ecological Indicators, 85, 808-819.

Leff, E. (2012). Latin American environmental thinking: A heritage of knowledge for sustainability. Environmental Ethics, 34(4), 431-450.

Leyva-Flores, R., Dr, I.-X., \& C., Gutiérrez, J.P., Quintino-Pérez, F. . (2013). Inequidad persistente en salud y acceso a los servicios para los pueblos indgenas de México, 2006-2012. Salud Publica Mexico, 55, $123-128$.

Lu, Y., Geng, Y., Liu, Z., Cote, R., \& Yu, X. (2017). Measuring sustainability at the community level: An overview of China's indicator system on national demonstration sustainable communities. Journal of Cleaner Production, 143, 326-335.

Ludwig, D. (2016). Overlapping ontologies and Indigenous knowledge. From integration to ontological selfdetermination. Studies in History and Philosophy of Science Part A, 59, 36-45.

Lujan Álvarez, C., Olivas García, J. M., \& Magaña Magaña, J. E. (2004). Evaluación estratégica del desarrollo forestal sustentable en Chihuahua. México. Región y Sociedad, 16(30), 85-116.

Mascarenhas, A., Coelho, P., Subtil, E., \& Ramos, T. B. (2010). The role of common local indicators in regional sustainability assessment. Ecological Indicators, 10, 646-656.

Mendoza Sánchez, H. (2011). Tradición y modernidad; al servicio de las poblaciones indígenas en Oaxaca?: el caso de Teotitlán del Valle (Doctoral dissertation, Université du Québec à Montréal).

Mistry, J., \& Berardi, A. (2016). Bridging indigenous and scientific knowledge. Science, 352, 1274-1275.

Moreno-Pires, S., Fidélis, T., \& Ramos, T. B. (2014). Measuring and comparing local sustainable development through common indicators: Constraints and achievements in practice. Cities, 39, 1-9.

Muller, S. (2012). Two ways': bringing indigenous and nonindigenous knowledges together. Country, native title and ecology, 59-79.

Ocampo, L., Ebisa, J. A., Ombe, J., \& Geen Escoto, M. (2018). Sustainable ecotourism indicators with fuzzy Delphi method-A Philippine perspective. Ecological Indicators, 93, 874-888.

Comisión Nacional Para el Desarrollo de los Pueblos Indígenas (CDI). (2006). Indicadores Sociodemográficos de la Población Indígena 2000-2005.

Preuss, K., \& Dixon, M. (2012). 'Looking after country two-ways': Insights into Indigenous communitybased conservation from the Southern Tanami. Ecological Management \& Restoration, 13(1), 2-15.

Quarrie, J. (1992). United Nations Conference on Environment \& Development Rio de Janerio, Brazil. Regency Press. Agenda 21.

Raymond, C. M., Fazey, I., Reed, M. S., Stringer, L. C., Robinson, G. M., \& Evely, A. C. (2010). Integrating local and scientific knowledge for environmental management. Journal of Environmental Management, 91, 1766-1777.

Richardson, B. J. (2011). The ties that bind: Indigenous peoples and environmental governance. Indigenous Peoples and the Law: Comparative and Critical Perspectives, 2009.SSRN Electron. J. 04. 
Sae-Wang, R. (2015). Spirit of the loom: the conservation and commodification of Surin's textile cultural heritage. International Journal of Intangible Heritage, 10, 86-100.

Sala, S., Ciuffo, B., \& Nijkamp, P. (2015). A systemic framework for sustainability assessment. Ecological Economics, 119, 314-325.

Sala, S., Farioli, F., \& Zamagni, A. (2013). Progress in sustainability science: Lessons learnt from current methodologies for sustainability assessment: Part 1. International Journal of Life Cycle Assessment, $18,1653-1672$.

Sancho, A., Garcia, G., \& Rozo, E. (2007). Comparativa de indicadores de sostenibilidad para destinos desarrollados, en desarrollo y con poblaciones vulnerables. Annals of Touism Research En Español, 9, 150-177.

Santana-Medina, N., Franco-Maass, S., Sánchez-Vera, E., Imbernon, J., \& Nava-Bernal, G. (2013). Participatory generation of sustainability indicators in a natural protected area of Mexico. Ecological Indicators, $25,1-9$.

Seingier, G., Jiménez-Orocio, O., \& Espejel, I. (2020). Vulnerability to the effects of climate change: Future aridness and present governance in the coastal municipalities of Mexico. In Stewardship of Future Drylands and Climate Change in the Global South (pp. 301-320).

Simpson, L. (2000). Stories, dreams, and ceremonies-anishinaabe ways of learning. tribal coll. Journal of American Indian Higher Education, 11, 26-29.

Red de Ciudades y Pueblos Sostenibles de Castilla-La Mancha. (2009). Panel de Indicadores de Sostenibilidad local para los Municipios integrantes de la Red de Ciudades y Pueblos Sostenibles de Castilla-La Mancha. https://docplayer.es/16679506-Panel-de-indicadores-de-sostenibilidad-local-paralos-munic ipios-integrantes-de-la-red-de-ciudades-y-pueblos-sostenibles-de-castilla-la-mancha.html

Sowińska-Świerkosz, B. (2017). Review of cultural heritage indicators related to landscape: Types, categorisation schemes and their usefulness in quality assessment. Ecological Indicators, 81, 526-542.

Sterling, E. J., Filardi, C., Toomey, A., Sigouin, A., Betley, E., Gazit, N., \& Jupiter, S. D. (2017). Biocultural approaches to well-being and sustainability indicators across scales. Nature ecology \& evolution, l(12), 1798-1806.

Tengö, M., Brondizio, E. S., Elmqvist, T., Malmer, P., \& Spierenburg, M. (2014). Connecting diverse knowledge systems for enhanced ecosystem governance: The multiple evidence base approach. Ambio, $43,579-591$.

Toumi, O., Le Gallo, J., \& Ben Rejeb, J. (2017). Assessment of Latin American sustainability. Renew. Renewable and Sustainable Energy Reviews, 78, 878-885.

Vanhulst, J., \& Beling, A. E. (2014). Buen vivir: Emergent discourse within or beyond sustainable development? Ecological Economics, 101, 54-63.

Velázquez-Sánchez, R. M., Gómez-Velázquez, J., Gaytán Bohórquez, L. I., Flamenco Hernández, A., \& Núñez Contreras, C. A. (2014). Indicadores Económicos, Ambientales Y Sustentabilidad Del Ecoturismo En México (Economic, Environmental and Sustainability Indicators of Ecotourism in Mexico). Revista Internacional Administración \& Finanzas, 7(7), 127-136.

Vivir.B. Ecuador-Quito, E.S.T. del S. N. (2013). Objetivos nacionales para el Buen Vivir

Wilson, S. (2003). Progressing toward an Indigenous research paradigm in Canada and Australia. Canadian Jounal of Native Education, 27(2), 161.

Yissi, J. F., \& Cartes, R. V. (2011). Calidad de vida, ocupación, participación y roles de género: Un sistema de indicadores sociales de sostenibilidad rural (Chile). Cuadernos De Desarrollo Rural, 8, 24-24.

Publisher's Note Springer Nature remains neutral with regard to jurisdictional claims in published maps and institutional affiliations. 


\section{Authors and Affiliations}

Jessica Molina Maturano ${ }^{1}$ (D) . Luz A. García Serrano ${ }^{1}$ (D) Juan A. Carmona García ${ }^{2}$ (D) . Mayela A. García de Alva Magos ${ }^{3}$ (D) . Anna M. Hersperger ${ }^{4}$

1 Interdisciplinary Center for Research and Studies on Environment and Development CIIEMAD, Barrio la Laguna Ticomán, Delegación Gustavo A. Madero, Calle 30 de Junio de 1520 s/n, C.P. 07340 México, D.F, México

2 Moscow State Institute of International Relations, Prospekt Vernadskogo, 76, 119454 Moscow, Russia

3 Biotic Product Development Center CEPROBI, CEPROBI street 8, C.P. 62731 Yautepec-Jojutla, México

4 Landscape Dynamics, Swiss Federal Research Institute WSL, Zürcherstrasse 111, 8903 Birmensdorf, Switzerland 